\title{
دور إدارة المدارس الثانوية العامة فى مواجهة التطرف الفكرى لدى طلابها \\ ( دراسة ميدانية بمحافظة الدقهلية )
}

\section{مشيرة أبو بكر حسن فودة}

المقدمة

وشهدت الأعو ام القليلة الماضية فـى

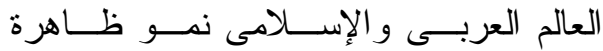

التطرف الفكرى خصوصاً لدى فئة الـشباب ، ما أدى إلى الإخلال بنعمة الأمن والأمان و هذا يؤكد على أن التصدى لظاهرة التطرف التى الفكرى لاتتم إلا بإحياء دور العقل ودر اســة الظروف الإجتماعية التى ساعدت على تفثى

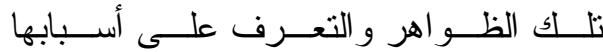
و أخطار ها ( الحوشان ، 10 • ب ، r I ). وانتشرت مظاهر التطرف الفكــرى بين فئات الشباب كان أوضحها اتجاه بعضهم نحو العزلة و السلبية و اتبع الـبعض الآخـر

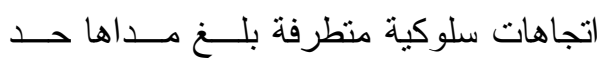
استخدام العنف ، وتعبر هذه الاتجاهات عـن من ثقافة شبابية تتسم بخاصية الرفض للمعـايير و القيم و السلطة فى المجتمع ، ولذا فـسرت بعض الكتابات الغربية ثقافة الــشباب علــى ولى

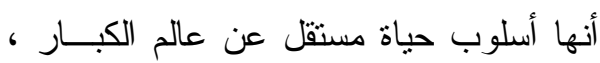

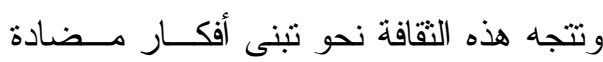
تعبر عن تحدى للقيم و المعايير التى يرتضيها المجتمع نفسه ، وكذللك قد يتزتب على ميـل الثباب المنز ايد نحو استقلاليته ، ومحاو لات
يرتبط التطـــرف الفكـــــى بالتـــدهور

الثقافى و العلمى و الإجتماعى و الإقتصادى فى المجتمع ، كما يعطل الطاقات الانسانية كافة ويستخدمها فى صر اعات وعدائات ويحــول دون تكامل المجتمع ، ويؤدى إلــى عجــز المجتمع عن التفكيــر فــى حلــول مبدعــة لمشكلاته و وعن تطوير ذاته ويــصبح تابعــــا

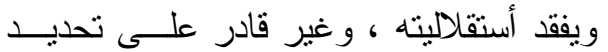
مصيره و مستقبله . مصنه ويعد التطرف الفكرى أخطر أنـــواع التطرف فكل جريمة فى الغالب مسبوقة بفكر منحرف ، ما يتطلب بذل كل جهذ ممكـن فى سبيل تحقيق الأمن الذى يعد من أعظـــ مرح

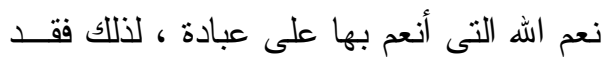
حان الوقت لتدخل جميع المؤسـسـات بقــوة وفاعلية لممارسة دور ها فى تحصين المجتمع ، ليتحقق التوازن مع ما يبذل عسكرياً وأمنياً لمو اجهة السلوكيات العدو انية و التى هى نتاج لإنحر افات فكرية وشعور سلبى قائم على قيم سلبية يؤمن بها الفرد وتؤثز فى سلوكه ومن هنا يتحول الثر إلى سلوك . ( الخميـسى

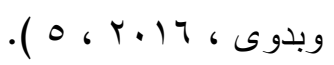


و القصور فـى ربــط دور الأســرة بــدور

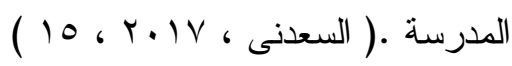

ويعد أسلوب الحوار و الديمقر اطية من

أهم أساليب التربية المناسبة لتربية الــشباب

و إرشادهم وتوجيهـم و إصلاحهم ووقايتهم من

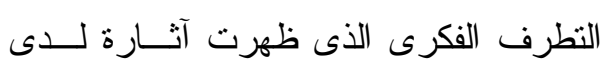

بعض الثباب ، فالحوار البناء معهم يشعرهم بمكانتهم الرفيعة ودور هم الكبير ، ويساعدهم على الفهم الصحيح ، كما أن الحوار يتيح لهم لهم ولئه فرصة للتعبير عـن حاجـاتهم ورغبــاتهم ومشكلاتهم بأسلوب مقنع ومفيد ويبــصر هم

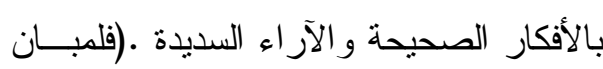

$$
\text { ( } \varepsilon \varepsilon_{6}, r_{\text {... }} \text { ، }
$$

وسوف يتتاول هذا البحــث مفهـوم

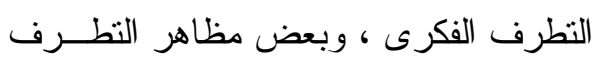

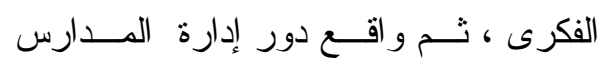

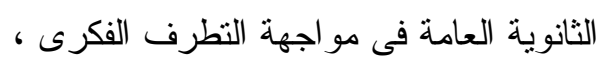

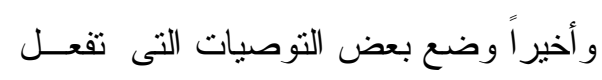

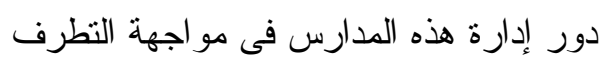

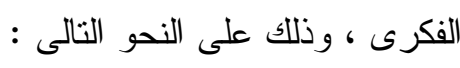

مشكلة البحث :

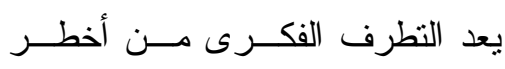

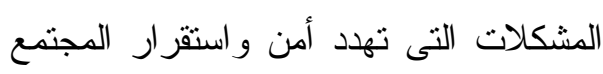
و أفر اده وخاصة فى المدارس الثانوية العامة،

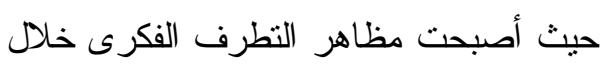

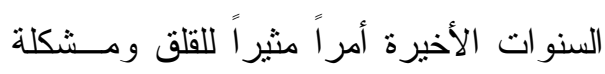

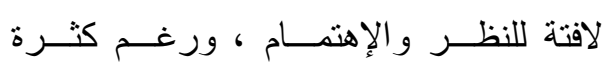

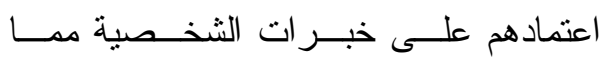
يعرضهم لمظاهر سلوكية تعبر عن الإستياء

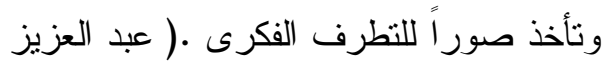

(r. r...q،

وتتادى التربية المعاصرة بتبنى نزبية

السلام بحيث تعلم الإنسان التحليل الناقد لكل مظاهر التطرف الفكرى و العنف ، وتربيــة السلام هى عملية منظمة لتمكين الفرد بالعلم

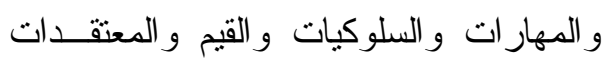

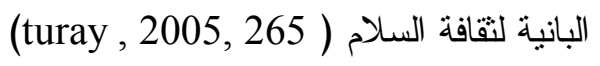

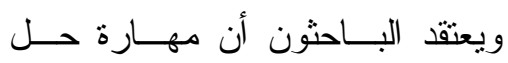

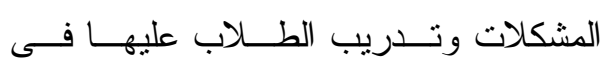
المدارس من التكنيكات الجيدة نزبوياً وهـى ونى

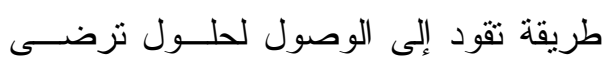

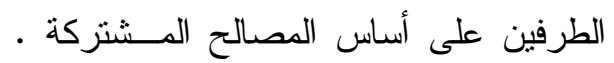
(Davies , 2004 , 293) ويلقى البعض اللوم على التربية مـن

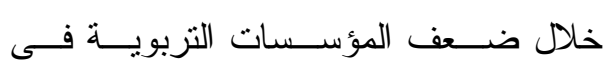

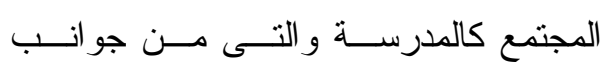
قصور ها التركيز على المادة العلمية وإغفال

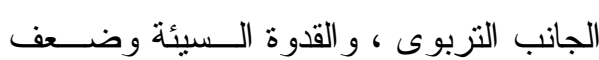
دور الإرشاد الطلابــى ، وعــدم مر اعــاة

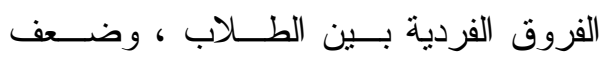

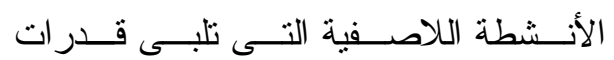

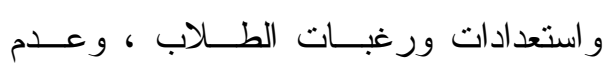

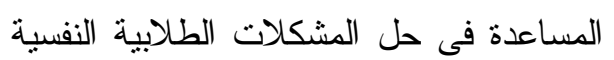

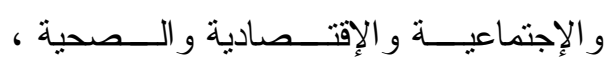


الدولى الأول للكلية حول مواجهة الإرهاب

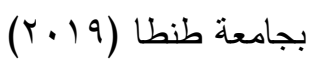

بتفعيل اللقاءات المباشرة مع الـشباب

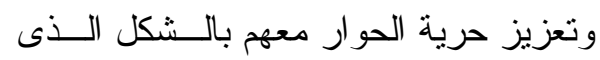
يمكنهم من التعبير عن أنفسهم و إبداء آرائهم

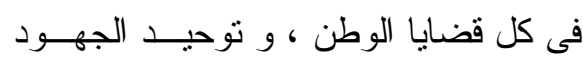

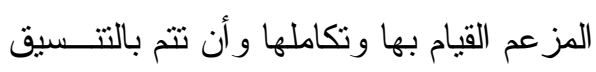

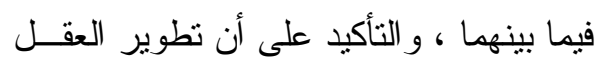

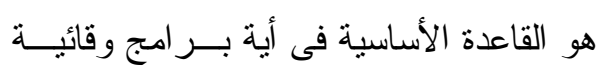

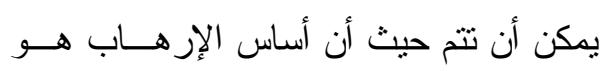
الفكر المتطرف الذى يجب ان توجه الجهود الإن البه لتغييره وتعديل المعتقدات الخاطئة التى ثقف

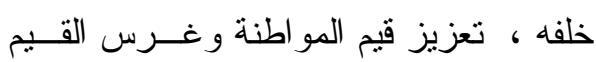
الإيجابية . حلفه كزيز

كما أكدت بعض الدر اسات الــسابقة

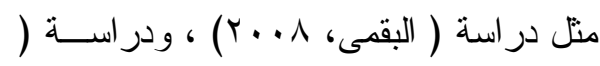

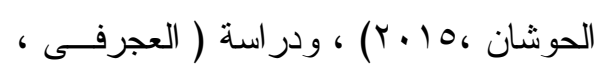

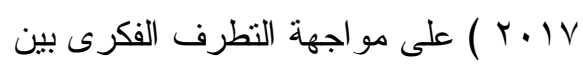

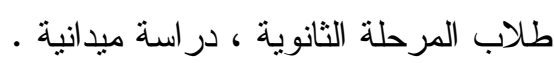
وهو الأمر الذى يؤكد أهمية التواصل

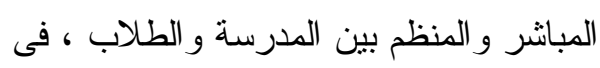

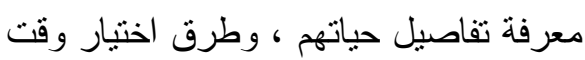

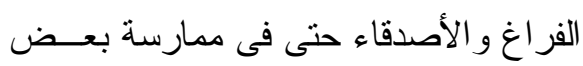

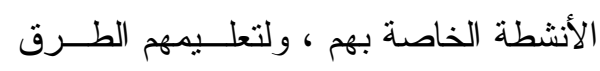
السليمة و الصحيحة فى كيفية اتخاذ القر ارات

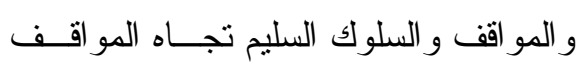
و المؤتمر ات و المتغير ات المختلفة .
التحليلات و التتاو لات الفكرية للمشكلة وتعدد زو ايا النظر ومنطلقات التحليل واختلافها فى ولى لئل المضمون ، ثقافياً ودينياً ونفسياً ، فقد لوحظ ونط

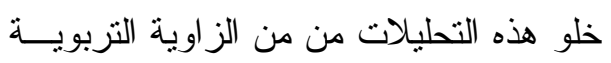

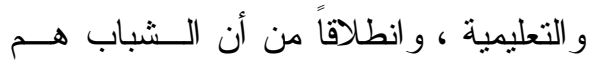

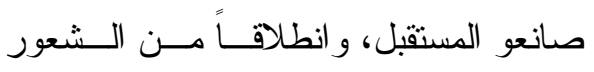
بالواجب المهني تجاه ضحايا الفكر المنطرف ونسف ممن غرر بهم و أصبحو ا يعتتقون فكر اً منحرفاً يتتاول هذا البحث ظاهرة النطرف الفكــري، حيث تكمن مشكلة الدر اسة في شيو ع ظاهرة التطرف الفكري، وتأثنير ها على فئة كبيرة من فئن

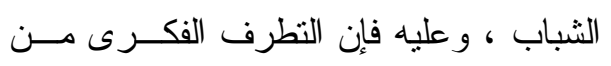

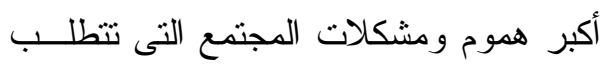

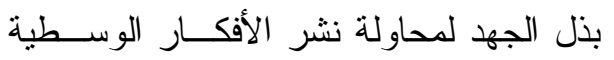

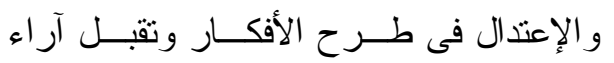

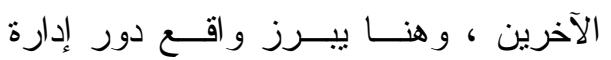

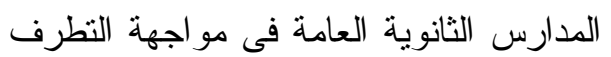
الفكرى لدى طلابها . وأن المدرسة هى المؤسسة الرئيسسة

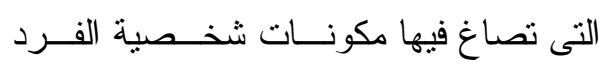
بجو انبها المختلفة ، وهذا الأمر فى حد ذاتــه

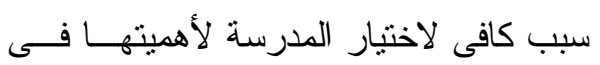

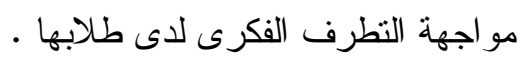
وهنــاك العديـــــــــن المـــؤتمرات و الدر اسات التى أوصت بضرورة مو اجهــة

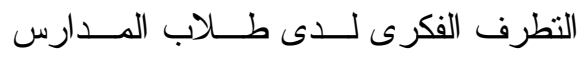
الثانوية العامة ، حيث أوصى المؤتمر العلمى 


\begin{tabular}{|c|c|}
\hline 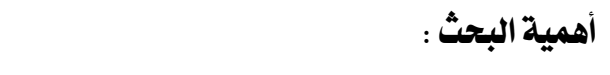 & وبناءً على ما سبق تتــــدد مــشكلة \\
\hline تتحدد أهية البحث الحالى فى الآتى : & البحث الحالى فى الوقوف علــى دور إدارة \\
\hline • - كون المدرسة هى المؤسـسـة الثانيــة & المدارس الثانوية العامة و عليه يمكن صباغة \\
\hline التى يكتــسب منهــــا الفـرد معارفـــه & البحث فى التساؤلات التالية : \\
\hline وخبر اته وسلوكياته الاجتماعيه وذلـــــ & 1- ما مفهوم التطرف الفكرى ؟ \\
\hline من خلال ما يتعرض له الفــرد مــن & r- ما مظاهر التطرف الفكرى لاى طلاب \\
\hline مثير ات تربويه ايجابيـــه تــسهم فــى & المدارس الثانوية العامة؟ \\
\hline تكوين شخصيته الذاتيه و الاجتماعيــــ & ــــــا و اقع دور إدارة المدارس الثانويـــة \\
\hline وهو ما يعزز من دور المدرسة فـى & العامة بمحافظة الدقهلية في مو اجهــة \\
\hline مواجهة التطرف الفكرى. & التطرف الفكرى لدى طلابها ؟ \\
\hline ا - ـــا يتعرض له الــوطن العربــى دــن & ع- مـا التوصيات لتفعيل و اقــع دور إدارة \\
\hline هز ات عنيفه من شأنها التــأثير علــى & المدارس الثانوية العامة فى مواجهــة \\
\hline المستوى القيمى و الخلقى لأبنائه ، وما & التطرف الفكرى لدى طلابها ؟ \\
\hline يتبع ذلك من أساليب للغزو الفكــرى & 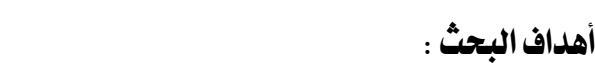 \\
\hline التى تؤثز بدورها على عقول الثباب . & يـاف البحث الحالى إلى \\
\hline 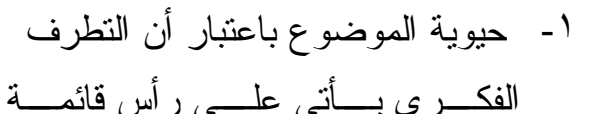 & 1- التعرف على مفهوم التطرف الفكرى \\
\hline 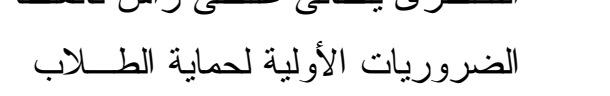 & r- التعرف على بعض مظاهر التطـــرف \\
\hline من التيار ات الفكرية الهذامة ـ . & العامة الفكرى لدى طلاب المدارس الثانويـــة \\
\hline 1 - أهمية الدور الذى تؤديه المدرسة فــى & \\
\hline وقاية الطلاب من الانز لاق فى تيار ات & r- الوقوف على و اقع دور إدارة المدارس \\
\hline التطــرف الفكــرى وتحـــصين أمــنـن & الثانوية العامة بمحافظة الدقهليــة فــى \\
\hline المجتمع و استقر اره ـ. & مو اجهة التطرف الفكرى لدى طلابها . \\
\hline منهج البحث & ـ - وضـــع بعـــ التوصــــات لتفعيــل \\
\hline يــستخدم البحــــث الحـــالى المـــنهـج & دور إدارة المدارس الثانويـــة العامـــة \\
\hline الوصفى، وفيه يتم التعــرف علــى مفهــوم & فى مواجهة التطـــرف الفكــرى لـــــى \\
\hline & لابها \\
\hline
\end{tabular}


وبيان الدور الذى يمكن أن تقوم به التربيــة،

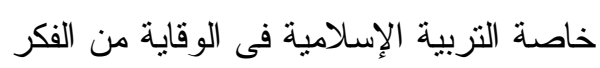
المتطرف .

و استخدمت الدر اسة المنهج الوصــفى التحليلى وذلك لأن هذا المنهج مناسب لمنــل هذه الدر اسة، و الاستبانة كأداة للار اسة ، وتن لـان

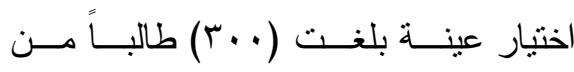
الجامعات السعودية

ومن أهم النتــائج التــى توصــلت إليهــــا

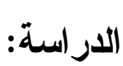
يمكن للتربية أن تسهم فى الوقاية من التطرف ، وذلك من خلال غرس مجموعـــة

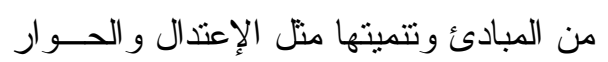

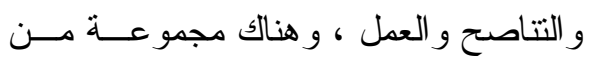
المؤسسات التربوية يقع على عاثقها الإسهام فى الوقاية من الفكر المتطرف ، و وتتمنل هذه

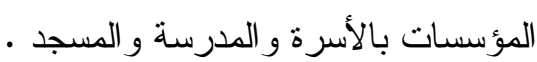

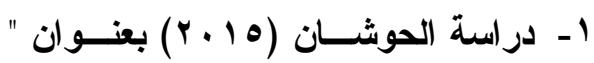

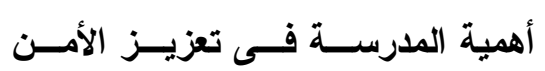
الفكرى" (معه

هدفت الدر اسة إلى تحديد مفهوم الأمن

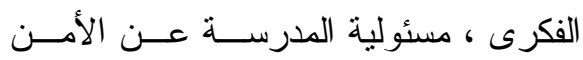
الفكرى ، طرق تعزيـز المدرســـة للأمــن الامهـن

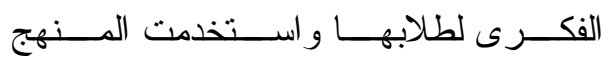
الإستقر ائى الإستتناجى التحليلى الـــى حلــلـل و اقع الدر اسات العلمية .

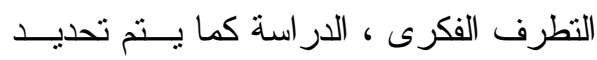

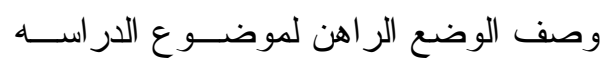

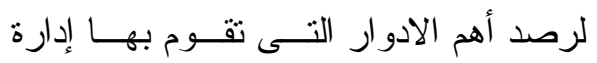

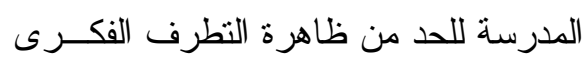
بين طلاب الثانوية العامة .

\section{مصطلحات البحث}

يعرف النطرف الفكرى إجرائياً بانه:

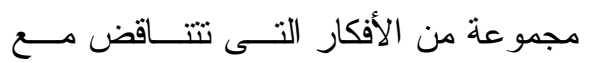

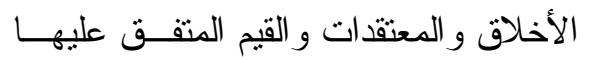
إجتماعياً ودينياً وثقافياً وهو نوع من الجمود

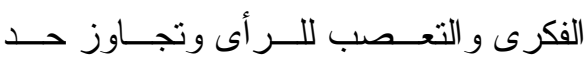
الإعتدال فيه . الدراسات السابقة : تم عرض الدراسات السابقة فى محورين : المحور الأول : الدراسات العربية :

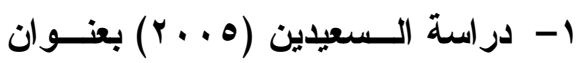
"دور المؤسسـات التربوية فى الوقايــة الونة

\section{من الفكر المتطرف}

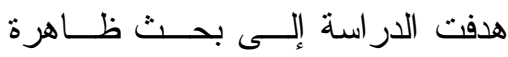

التطرف وفهمها وتقصى جو انبها ، وذللك من لن

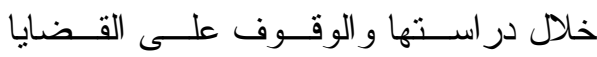
و الجوانب الجزئية الآتية : إلقاء الضوء على

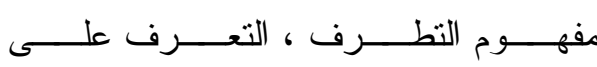
جذور التطرف فى الفكر الإسلامى ، الكثف ، عن الأسباب و العو امل المؤدية إلى تـشكيل

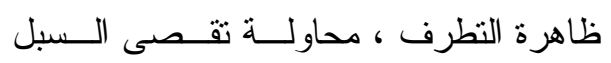
و الحلول الكفيلة بالوقاية من ظاهرة التطرف، 


$$
\begin{aligned}
& \text { هدفت الدراسة إلى وضـــع تــصور }
\end{aligned}
$$

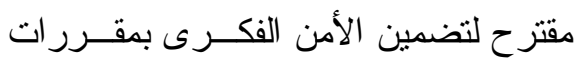

$$
\begin{aligned}
& \text { التزبية الإسلامية وبيان أثره على تتمية قيم لمنرين } \\
& \text { المو اطنة لدى طلاب المرحلة الثانوية . }
\end{aligned}
$$

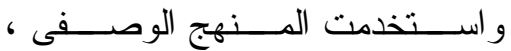

$$
\begin{aligned}
& \text { ولدر اسة أثز التصور المقترح تم اســتخدام } \\
& \text { المنهج التجريبى و التصميم التجريبى الثـــائى } \\
& \text { ( قبلى - بعدى) ، وكانت عينــة الدر اســة فئمة } \\
& \text { عشو ائية من طلاب الــصف الأول الثــانوى } \\
& \text { بمدرستين بمدينة تبوك إحــــاهما مجمو عـــة }
\end{aligned}
$$

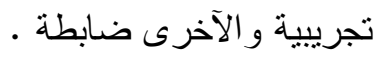

$$
\begin{aligned}
& \text { ومن أهم النتــائج التــى توصــلت إليهـــا }
\end{aligned}
$$

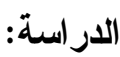

$$
\begin{aligned}
& \text { إن الأمن الفكرى مــدخل هــام جــداً }
\end{aligned}
$$

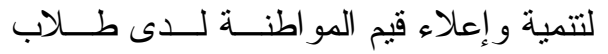

$$
\begin{aligned}
& \text { المرحلة الثانوية }
\end{aligned}
$$

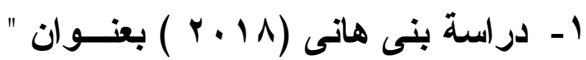

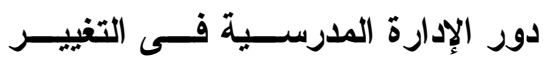

$$
\begin{aligned}
& \text { القيمى تجاه ظاهرتى الإرهاب و التطرف } \\
& \text { وسبل تطويره } \\
& \text { هدفت الدراسة إلى التعرف على دور } \\
& \text { الإدارة المدرسية في التغيير القيمسي تجــاه } \\
& \text { ظاهرتي الإرهاب و التطـــرف، مــن خــلد } \\
& \text { در اسة ميدانية، كما هدفت الدر اسة إلى بيان }
\end{aligned}
$$

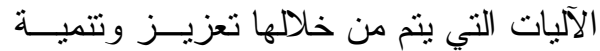

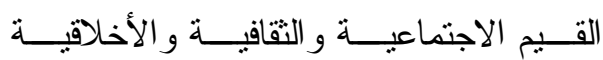


ومن أهم النتائج التى توصلت إليهــا

الدراسة أن هناك ارتباط بــين المتطلبــات

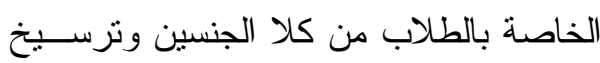

مفهوم الأمن الفكرى لديهم ، كما أن هنــالك

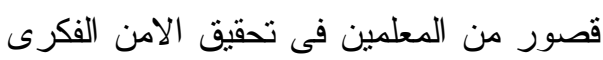

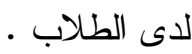

r- دراسة ( Nakpodia,2010) بعنوان "

الثقافة وتطوير المناهج فى المـــارس

النيجيرية ".

و هدفت الدر اسة إلى توضيح الثقافــة

وأنو اعها المتهددة ودر اسة أثز الثقافة علــى توضى

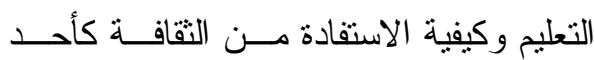
الطرق المؤدية إلى مواجهة التطرف الفكرى ، وماهو المقصود بالتطرف الفكرى و العلاقة لهونة بين التز اكم الثقافى و المعرفــى فـى عقـــل

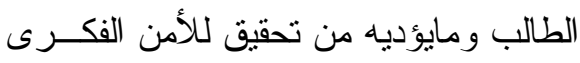

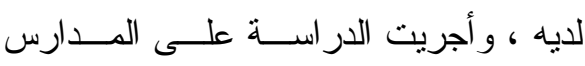
النيجيرية بتدقيق الرؤية فى المناهج الدراسية

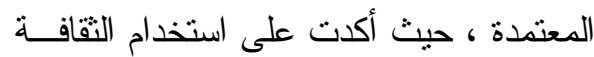
كأحد الأسس التزبوية ، وما يقتضيه ذلك من

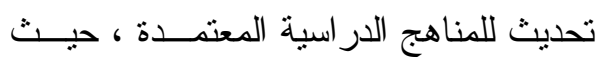

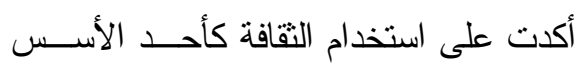

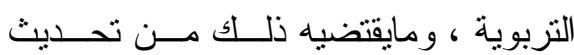

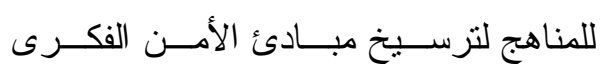

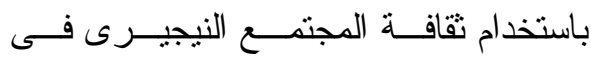

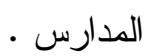

و السياسية لدى طلبة المرحلة الثانويـــة فــي مدارس مديرية تربية إربد الأولى.

واستخدمت المنهج الوصفى التحليلـى

فى تفسير النتائج ، وكانت عينة الدر اسة من

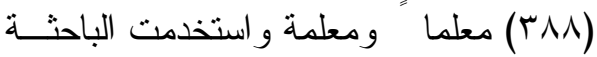

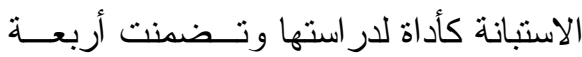

ومن أهم النتائج التى توصلت إليها الدراسة ب - لا توجد فروق ذات دلالة إحـصائية

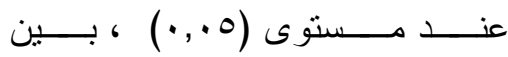
استجابات معلمي ومعلمات المرحلــــة الثانوية في مديرية تربية إربد الأولى وملى نحو دور الإدارة المدرسية في التغيير

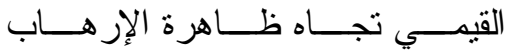
و التطرف لمتغير ات الدر اسة ( الجنس ، المؤهل العلمى ، سنوات الخدمة ) المحور الثاني : الدراسات الأجنبية : Guzzetti \& William ) دراســة 2004, ) بعنوان " فحـص التطــف

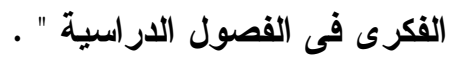
هدفت الدر اسة الوقوف علــى مـــدى

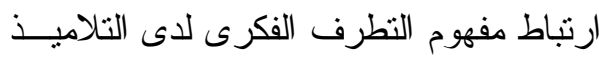
بالإختلافات الجنسية ، وذلك عـن طريــن

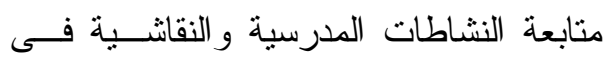
مختلف فصول التعليم ، و استخدمت الدراسة ولة منهج در اسة الحالة . منول 
أظهرتها نتائج الد راسة، ذلك بتعزيز الجانب

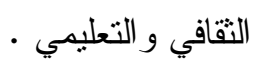

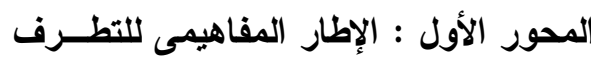
الفكرى قد بدء التطرف الفكرى بالتو غل إلـى

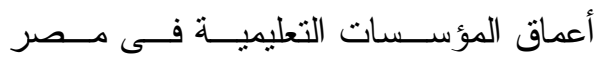
و الوطن العربى ، خاصة المدارس الثانويـــة

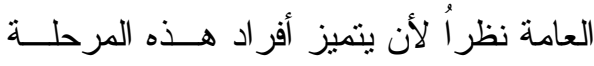

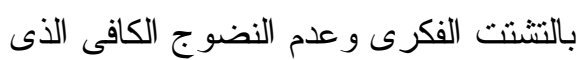

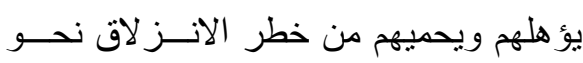

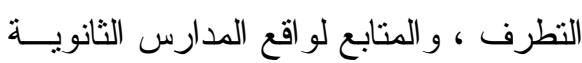

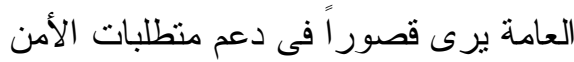

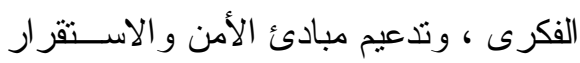
وضعف قدرة تلك المؤسسات على التو افــق ولق

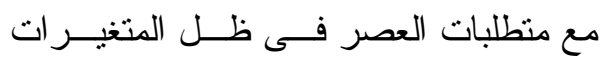
المتسار عة فى الأوضاع المجتمعية المختلفــــة

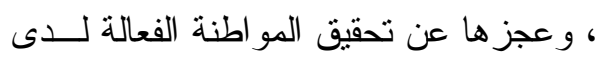

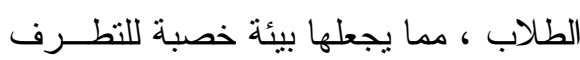

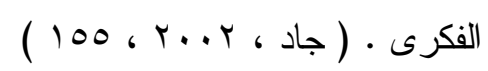
أولاً : مفهوم التطرف الفكرى

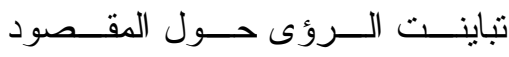

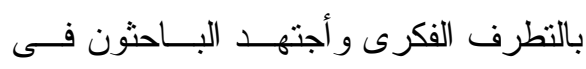

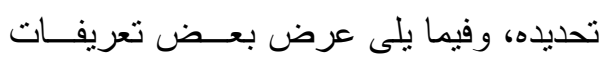
النطرف الفكرى : يعرف التطرف الفكرى بأنه الإبتعـاد

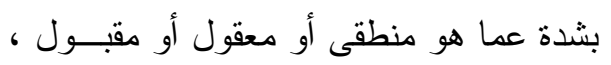

ومن أهم النتــائج التــى توصــلت إليهــــا

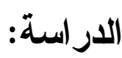
إن الإهتمام بالثقافة كأساس تربـــوى

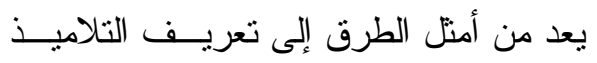

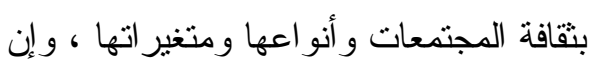
استخدام مكونات المنــاهج الدر اســية ومــــا تحتويها من ثقافات للمجتمع هى أحد الوسائل

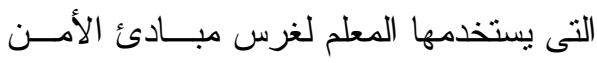
الفكرى لاى الطلبة .

ه- در اســــة ( Davydov, 2015 ) بعنوان" أسباب التطرف لدى الـشبباب

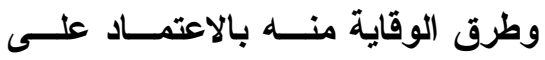
المؤسسات التربوية" . هدفت الدر اسة إلى التعرف علـى أسباب النطرف لدى الثباب وطرق الوقايـــة منه بالاعتماد على المؤســسات التربويـــة، ولتحقيق هدف الد ارسة تم استخدام المــنهج

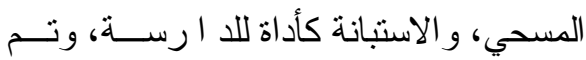
اختيار عينة من الخبر اء في التربية ومكافحة والنة النطرف بلغت ( 70 ) خبيرًا . ومن أهم النتائج التى توصلت إليها الدراسة القصور في أدوار المؤسسات التربوية ، انخفاض ثقافة التسامح في المجتمع ، وتدفق

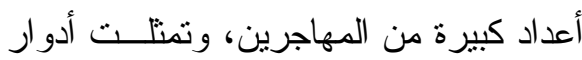
المؤسسات التربوي المأمولة في الوقاية مــن فئن

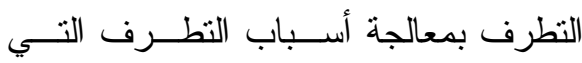




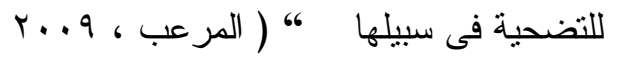
. ( r V 。

ويذكر آخر بأنه ، إغفــال الأســرة

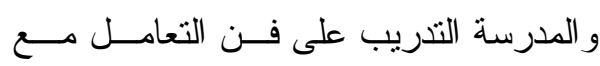

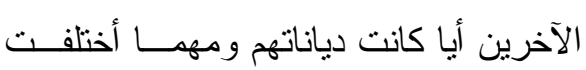

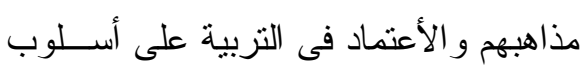

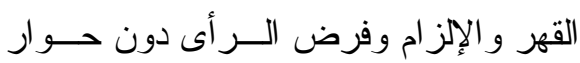

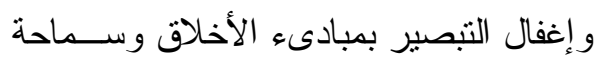
الاديان و الحوار المتبادل حتى يمل الأقنـــاع

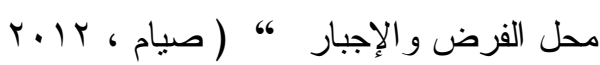
(10،

ويشير التطرف الفكرى إلى 6، تجاوز

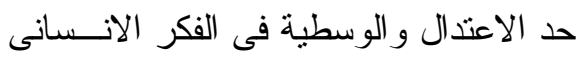
الذى قد بتزتب علية سلوكيات ضارة بـالفرد و المجتمع فى مختلــــ النـــواحى الـــياسية

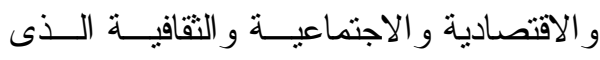

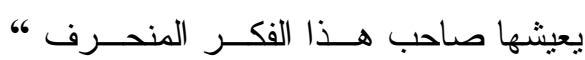

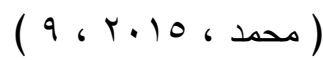

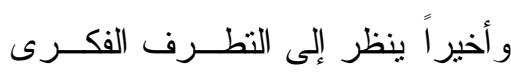

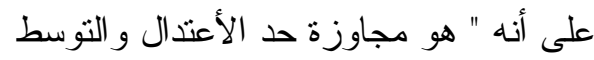

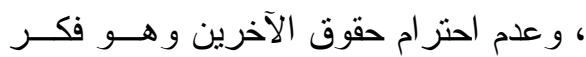
يخالف القيم الروحية و الأخلاقية و الحضارية

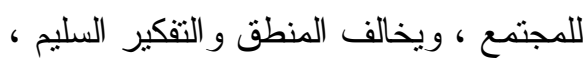

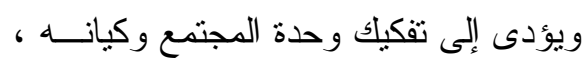
ونشر العنف وزعزعة الاستقرار الإجتماعى ولى وحنى

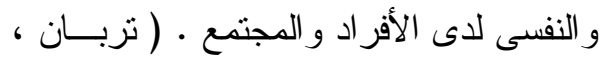

كـالتطرف فــى الــر أى ، وتـشير كلمــة (Extreme)

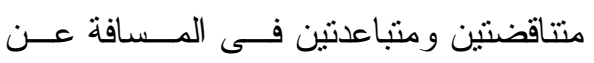

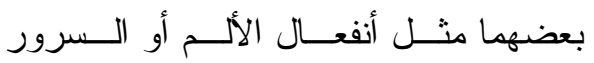
. ( webster,1984,316 )

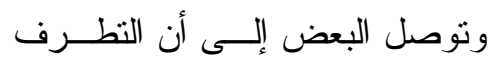

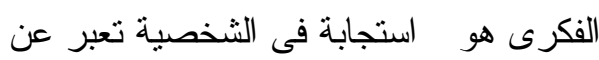
الرفض و الإستياء تجاه ماهو قائم فى المجتمع حيث تعكس مجموعة من الخصائص المميزة للثخصية المنطرفة إلى نهج مجموعة مسن

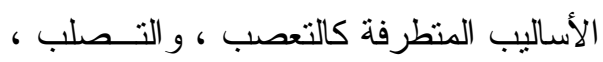
و الجمود الفكرى . (Larsson, 2005, 9 ) ويرى البعض أن النطرف الفكرى هو

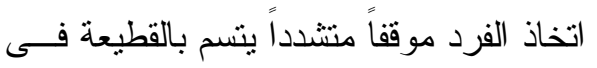

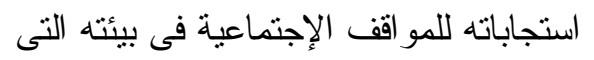
يعيش فيها ، وقد يكون التطرف إيجابياً فـى لـ الإنى

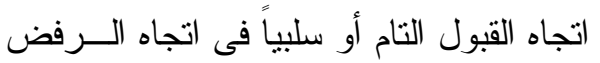

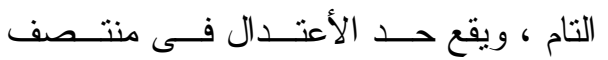
المسافة بينهما (Bolder , 2006 , 17) في حين ينظر إليه البعض على أنه ،

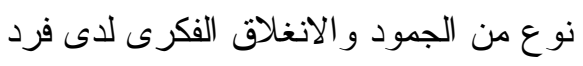

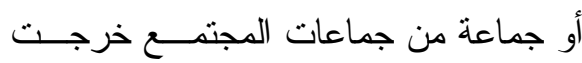
بفكرها حد الاعندال ، و على ما نو اضع أفر اد هن

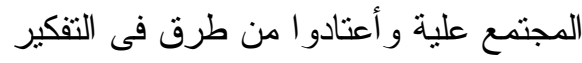

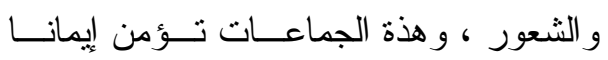

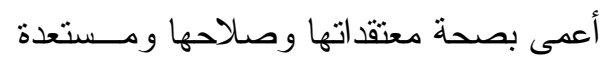




$$
\text { - - رفض المناقشة والحوار : }
$$

بعض الطلاب أخذوا بعض الأمــور

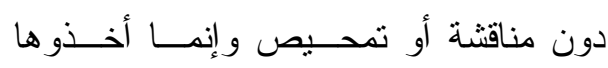
مسلمات غير قابلة للنقاش ، وهؤ لاء ألاء الطلاب

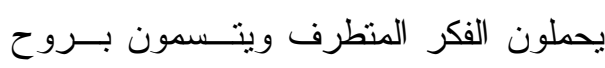
التخريب يلحظ عليهم خــصائص مـشنتركة

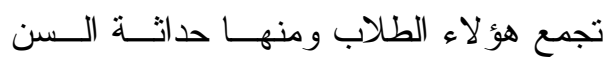

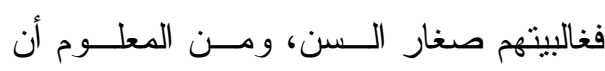
صغار السن هم أكثر رغبة فـــى المغـــامرة

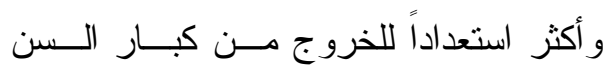

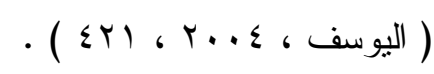

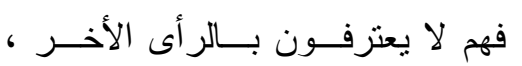

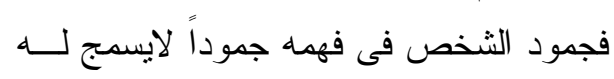

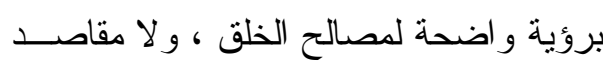

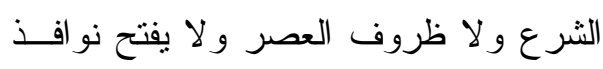

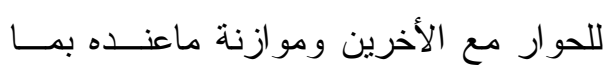

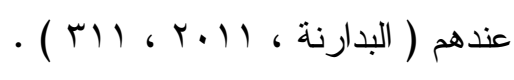
و الحوار يقضى على التطرف الفكرى

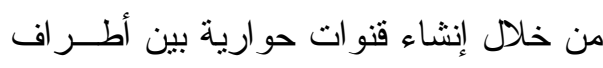
المجتمع المدرسى يسمح لكل طرف أن بتفهم

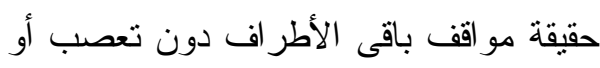

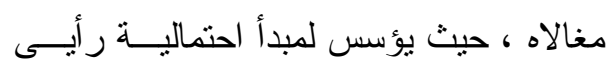

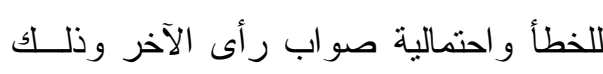
عن طريق دراسة آراء و أفكار باقى أطر اف والف ودئ

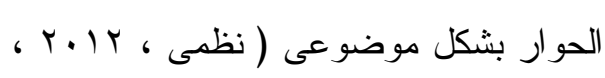

. $(\wedge \mathrm{V}$
وبذلك يمكن تعريف التطرف الفكرى

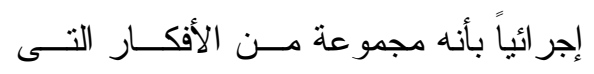

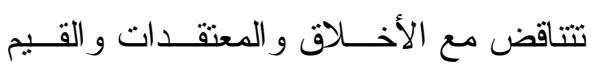

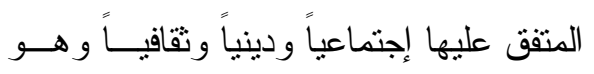

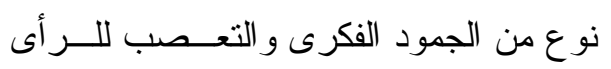
وتجاوز حد الإعتدال فيه . ثانياً : مظاهر التطرف الفكرى الاعثر فئ

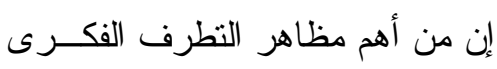

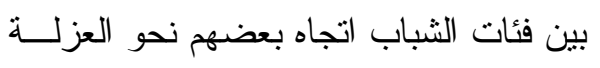

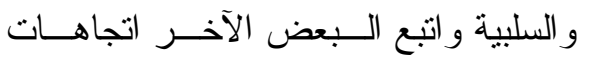

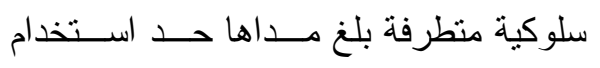
العنف، وتعبر هذه الاتجاهــات عــن نقافــة فئة شبابية تتسم بخاصية الرفض للمعايير و القيم

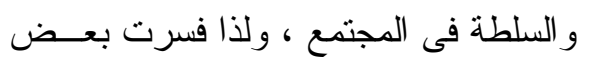

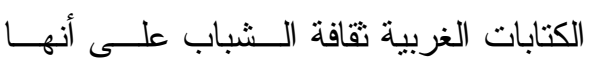
أسلوب حياة مستقل عن عالم الكبار ، وتتجه

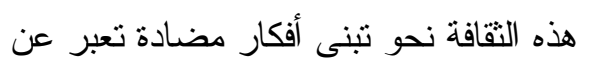

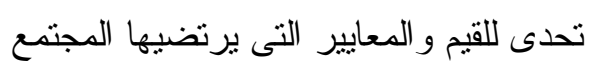

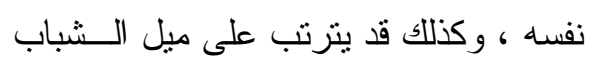

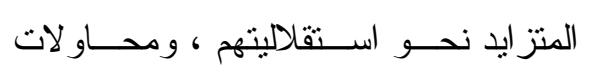

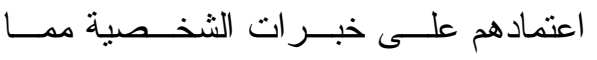
يعرضهم لمظاهر سلوكية تعبر عن الأستياء

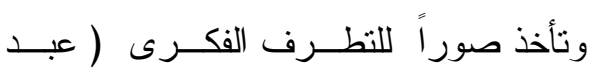

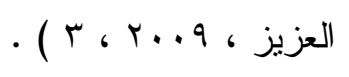
ويمكن عرض بعض مظاهر التطرف الفكرى لدى طلاب المدارس الثانوية العامـــة فى النقاط التالية : 


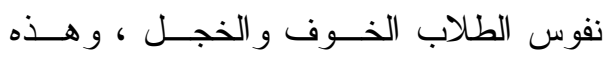

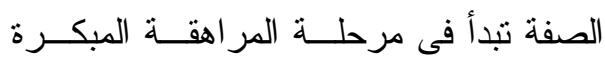

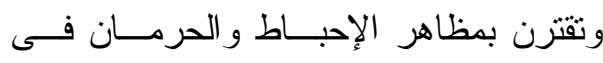

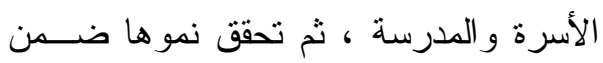
مواقف الإقتران المتكرر للفعل وسط جماعة

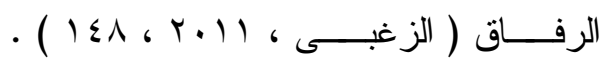

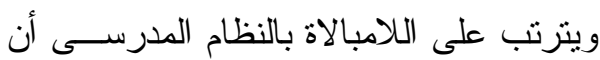

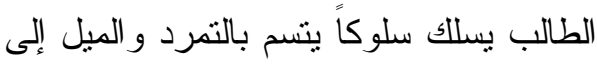

$$
\text { التخريب. }
$$

بالإضـافة إلى تحدى الطلاب للقـــوانين

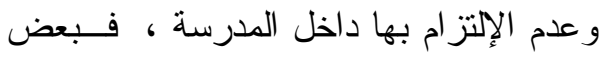

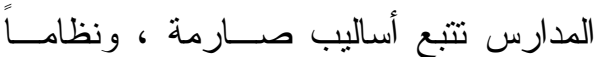

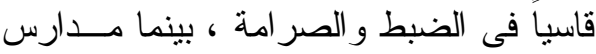
أخرى معروفة بالتسيب و الفوضى و اللامبالاة

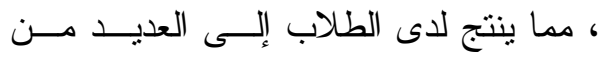
المشاكل السلوكية التى تجعلهم فى حالة مــن اللامبالاة مع المجتمع المدرسى كالفوضـى وعدم النظام ، و السلوك العدو انى المصحوب

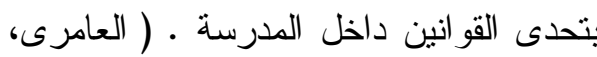

$$
\text { • (1) ، r... } 9
$$

\section{ـ - ضعف المشاركة فى الأنشطة الطلابية :}

يعمل النشاط الطلابى على العديد من

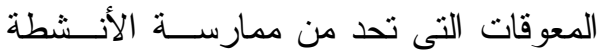

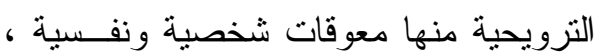
وقلة المعرفة بالبرامج وقلة أماكن الأنـشيطة وقلة أو الأستمر ار الموارد المادية فيها منها. مما (Alexandris,et,al ,2002 , 325 )
ومن هنا بمكن القول أن الحوار هــو

السبيل الوحيد إلى حـل جميــع مـشكلات المجتمع المدرسى وتجنب الصر اعات و أنهاء كل أثنكال التطرف ، إذ به تضييق الهوة بين

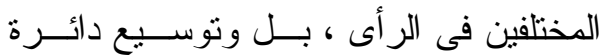

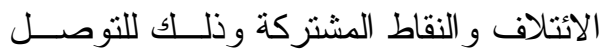
إلى الحقيقة و إقامة الحجة ودفع الفـساد مــن

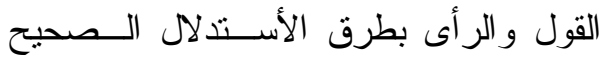

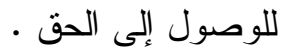
r-العنف فى طرح الآراء الفكرية : ! هنالك أزمة كبيرة ناتجة عن مقاومة الطلاب ضد آر ائهم الفكرية ولسوء الحظ فإن هذه العقليات المتحجرة و المتزمتة لا نزى فى بعض السلوكيات سوى الجانب السلبى منها ،

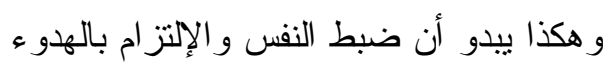
وعدم مجار اة الطالب في ميوله المتطرفـــة ،

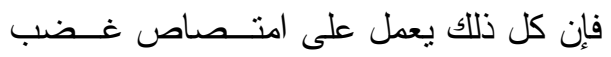
الطالب المنفعل ، كما أن أســلوب الحـــوار البناء يستهدف احتو اء السلوكيات الإنفعاليــة غير المنضبطة ، وبذلك يتمكن هذا العمل من تحقيق هدف الإلتفاف على سلوكيات الطلاب غير السوية .( أثنهبون ، V. . . r ، • (1) . ץ- اللامبالاة بالنظـــام والقـــوانين داخــل

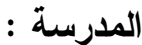

من أهم السمات الثخـــية المميـزة

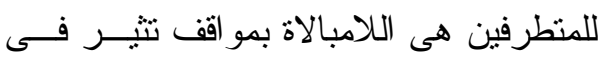


عما ينلقاه فى حصص التزبيــة الوطنيـــة ،

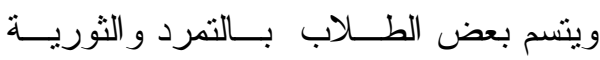

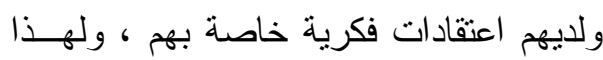

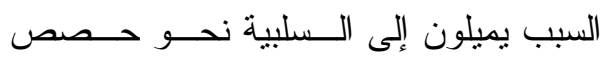
النزبية الوطنية لما فيها من اعتقادات تخالف لمبلف

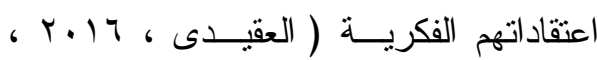
.170

فى حين أن التربية الوطنية مهمة جداً

لإعداد الطالب وفق فلسفة المجتمع التى يقوم عليها ويحتاج الطالب إلى تتويره بالمعرفـــة و القيم و المهار ات التى تساعده فى أداء دوره

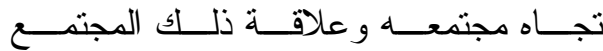
بالمجتمعات الآخرى وتأثنيره وتـــأثره بهــــا ، فأهميتها فى إعداد المواطن الصالح بضرورة تزويد الطالب بالعارف و القيم التـى تتــى لـى

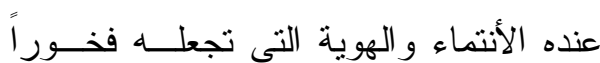

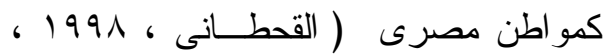
. (r) وهــــا لا يتــأتى إلا إذا جعلنـــا مــن

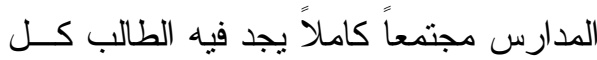

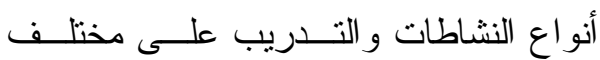
الأعمال الحيوية وفرصة الإحتكاك و التفاعل

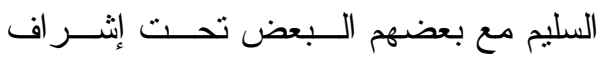

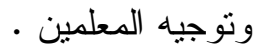

يؤدى بالطلاب إلى البحث عن البديل لشغل أوقات فر اغهم وتفريغ طاقاتهم . ه - ت تخريب أثثاث المدرسة

يجب على المدرسة استشتعار أهيــة كثف مشكلات الطــلاب قبــلـل اســتقحالها

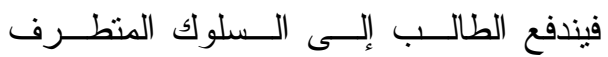

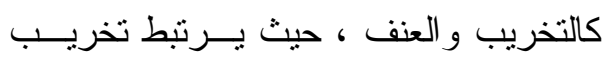

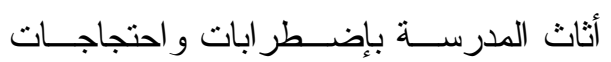
و اتتفاضات الطلاب الذين يعبرون من خلاله على تذمر هم ورفضهم لأوضاع تربويـــة أو

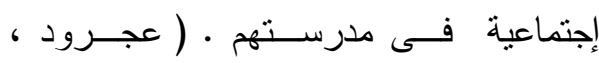
. ( r T \& ، r..V وتخريب الأثاث المدرسى من مظاهر

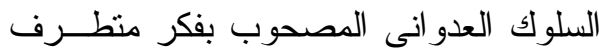

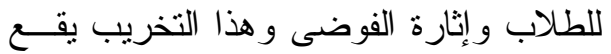
داخل حدود المدرسة .

צ- الإتجاهات السلبية نحو حصص التربية الوطنية : - الاجناه يتميز الطلاب فـى هــــه المرحلــة العمرية بنمو القــدرات الذهنيــة كــالتفكير

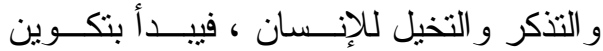

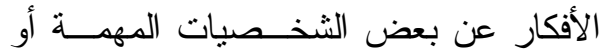

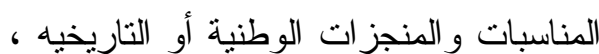

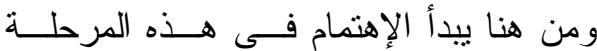
بإنضاج أفكاره حول الوطن و التربية الوطنية و النظام السياسى بشكل أكثر تفصيلاً ودة ولــة 
شأنهم إذا ذكرت شخصية وطنية عظيمسة أو

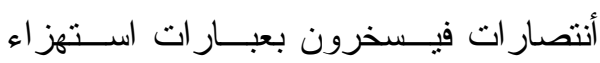

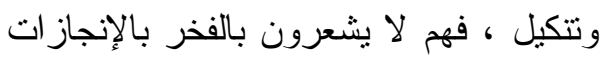

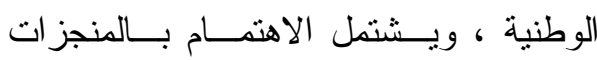
الوطنية و الإهتمام بالتثقيف السياسى للناشئيين بما ينمى فيهم أوجه المعرفة وما نفترض أن بالن التهام

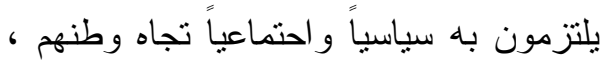

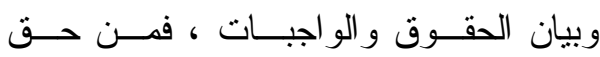
المو اطن أن ينال ما قرر له من حقوق مقابل

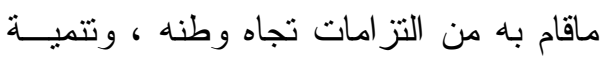

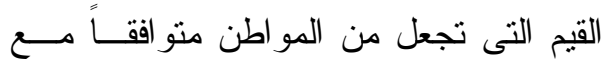

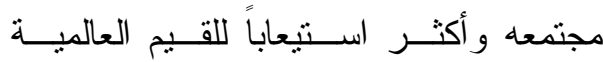

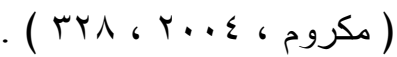

م- الروئة الـسطحية لــبض المـشكلات

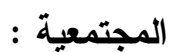

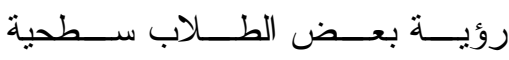

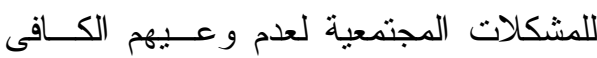
بالمجتمع ومشكلاته ويترتب على هذه الرؤية الخاطئة اعتقادات ساذجة منها ما يمكنه تغيير

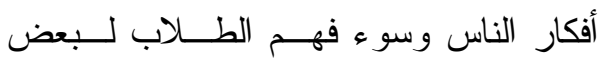
المو اقف التى يمرون بها ـ

نستخلص من ذلك أن عـدم شــور

الطالب بالإنتماء يجعله لا ينتمى لقيم وثو ابت

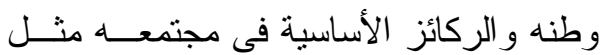
السخرية من الرموز الوطنية وعدم امتثالــهـ لقو انين و أنظمة المدرسة . ل
V - تـــــى تعليــــات وتوجيهــــات إدارة

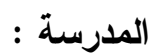

تعتمد التزبية الجديدة علــى وجـود

إدارة نربوية رشيدة تقود عملياته وفق منطق لقان الثفافية فى الأداء ، والإخلاص فى العدــل و المقصد و الرقابة فى التتفيذ ، و إدارة تتمكن

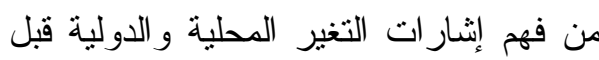
أن تنتجيب له وفق رؤية و اضــــة المعـالم

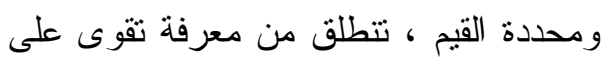

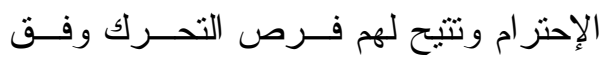

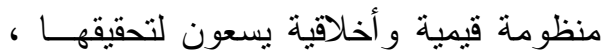

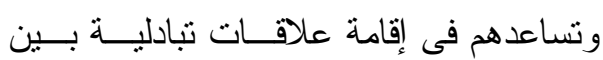
العناصر المشاركة فيه ويحقق له نوعاً مـنـ لهن

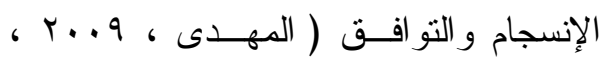
كTV ) ، فلابد للحد من السلوكيات الـسلبية غير المقبولة التى بدأت نتتامى فـــى الآونـــة

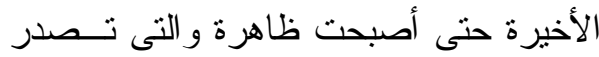
من بعض الطلاب فى تحدى نوجيهات إدارة

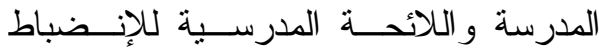
وتتضمن هذه اللائحة مجموعة من المخالفات

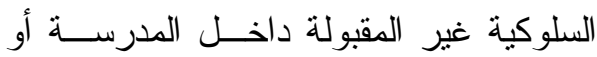

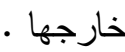

^- السخرية من بعض الرمــوز الوطنـــة و المنجزات الوطنية :

سخرية بعض الطلاب من الرمــوز

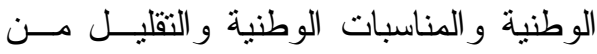


الإدارة الآخــــرى و الإتــــــال التزبـــــى

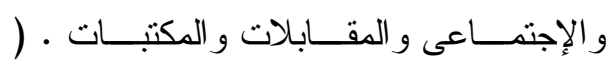

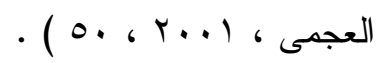

ويزداد الشعور بأهمية دور الادارة

المدرسية فى التغيير القيمى تجـــاه ظــــاهرة

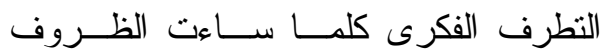
الاجتماعية و السياسية والاخلاقية التى يتبناها الافر اد فى مجتمعاتهم ، و عليه تقوى الحاجة

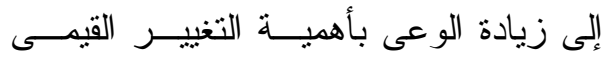

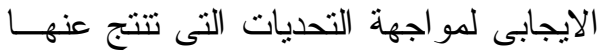

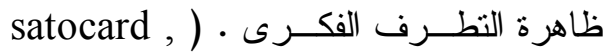

$$
\text { - ( 2013, } 26
$$

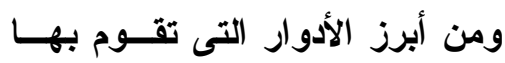

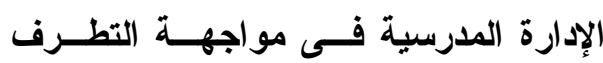

$$
\text { الفكرى ما يلى : }
$$

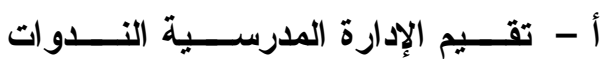
و المحاضرات لتوعية الطلاب بالقضايا

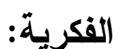

فى سبيل بنــاء الشخــصبة الــــوية

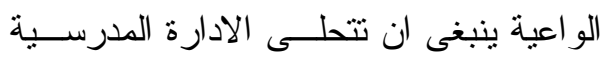

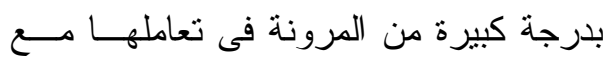

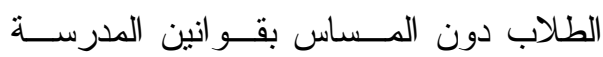
ونظامها وبعض هذه الاجر اءات منها: العناية

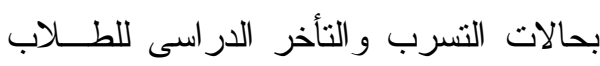
التى قد تكون سبياً فى انصر اف الطالب عن
المحور الثانى : دور الإدارة المدرسية فى مواجهة التطرف الفكرى . تعد الإدارة المدرسية ركنا هاما فـى

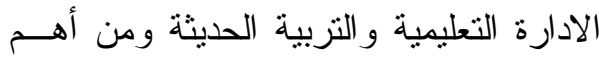
تشكيلاتها لانها تتولى تتفيذ السياسة التعليمية

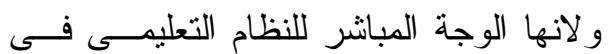

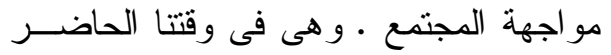

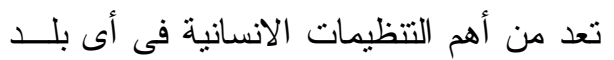

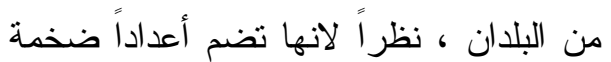
من الطلاب لذلك نلقى على عاتق المدرســة

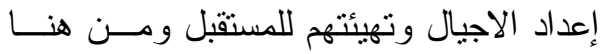
كانت مكانة الادارة المدرسية فــى الميــدان

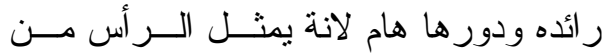

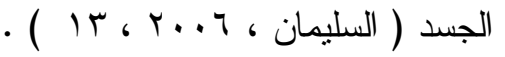
فإن الإدارة المدرسية لم تعد مجــرد النظام أو الضبط و الرباط وليست مجرد تتفيذ

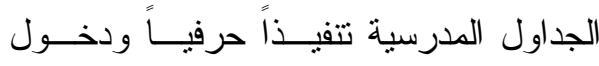
المعلمين حصصهم فى الأوقات المحددة لهم وللحصص ، ونظراً لأن الإدارة المدرسية لم الاوفين

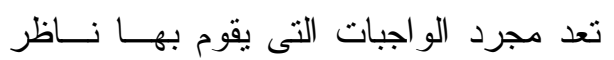

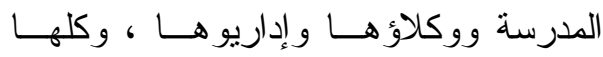
أصبحت تضم كافة العاملين بالمدرســة لأن وأن

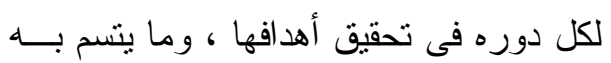
القائمون على إدارة مدارس التعليم العام من لهن سمات وتصنيفات مختلفة ، ومايتم بداخل تلك ملك المدارس من عمليات إدارية تشمل بجانــب

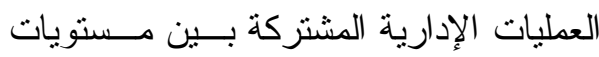


ويستتد هذا النمط فى نظرته لتفسير الــسلوك الإنسانى إلى الإنسان الذى يرغب فئى في العمل

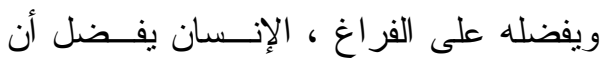

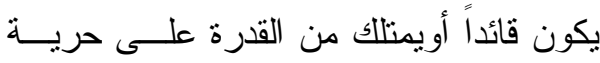
العمل و الإلتز ام و الو لاء للوطن ، وكذللك فإن وجود نظام مدرســى ديمقر اطـى ، ، و إدارة

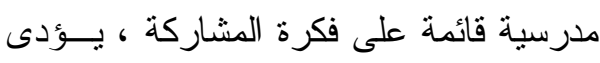
إلى إثـــباع الحاجــات الماديـــة و المعنويـــة

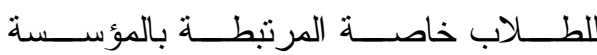

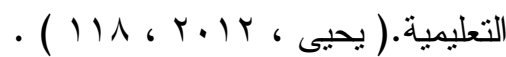
وتتعامل الإدارة المدرسية الديمقراطية

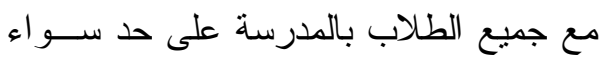

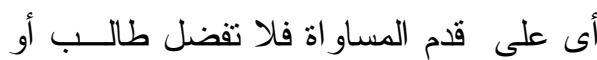

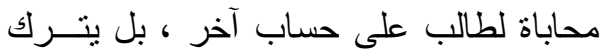

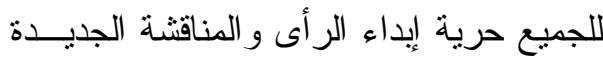
فى حرية كاملة ، ودور المـدير فيهــا دور

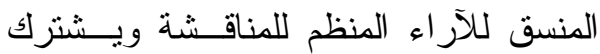
بالر أى فيها للوصول على الرأى الجمــاعى واء التابع من المشاركة الجماعيــة أو بأغلبيـــة الأعضاء و أهم مايميز هذا النمط هـــو عــدم التعصب لرأيه و عدم الأخذ لمبدأ الفردية فى هي هائ

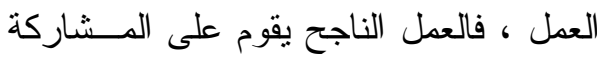

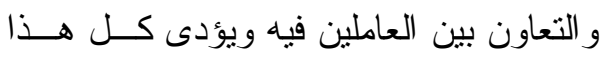

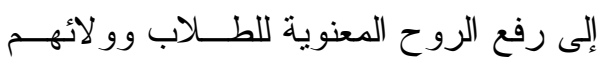

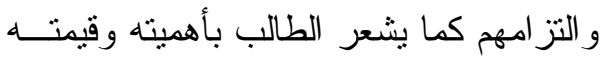
ويتحلى النمط الديمقر اطى بالأخلاق الفاضلة

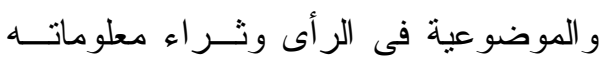

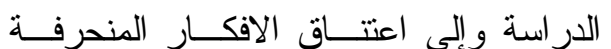

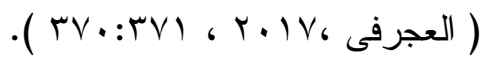
وكذلك تــشيع الطـــلاب علـــى أداء العبادات من خلال نوفير أماكن للصلاة وقيام

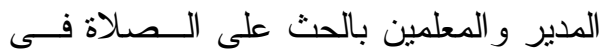
جماعة ، وتوزيع نشرات ومطويات ولوحات

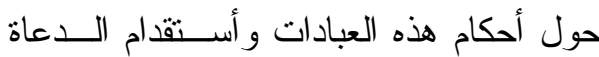
و المرشدين لعقد ندوات ومحاضرات حـول القضايا الدينية المعاصرة التى تـشغل ذهــن الطلبة ، وتزكية النفس و الارتقاء بها وتعزيز

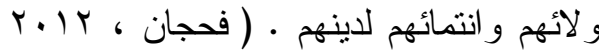
. $(\leqslant 0$ ،

فالدور الفعال لــلإدار ات المدرســية

يساعد فى جـــب الطــلاب نــــو العمليـــة

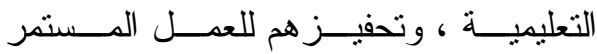

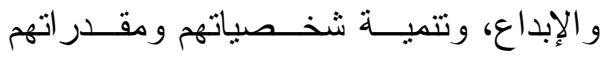

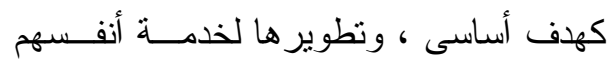

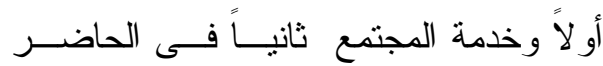

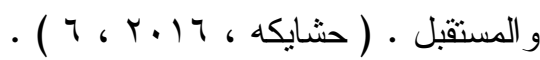
ب - تثشئة الطــلاب علــى احتــــام آراء الآخرين :

يعد النمط الإدارى الديمقر اطى مـن

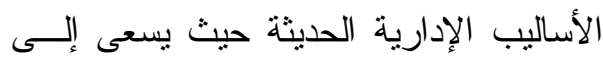
تحقيق أهدافهم من خلال اســتخدام وســائل الثو اب و المكافئة المادية و المعنويــة لتحفيـز

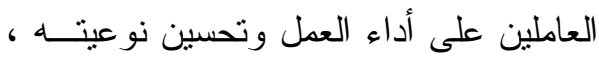


المعلمين فإن المعلمــين بــدور هم يقيمــون

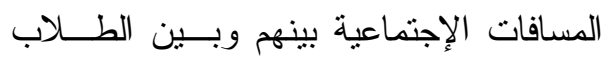

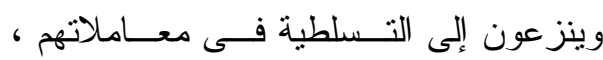

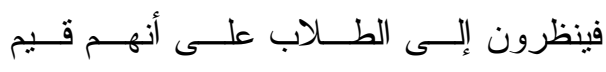
و أثخاص بل مجرد أثنياء يــدفعونها دفعــاً كيفما يريدون فى الإتجاه الذى يريدونه بغير

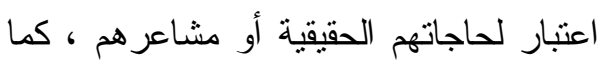

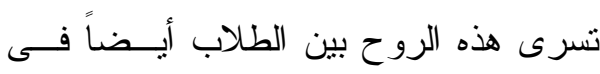
علاقاتهم ببعضهم البعض وفى التذلل لمن هم لهم لين أقوى ، و التسلط على من هم أضعف مــنهم

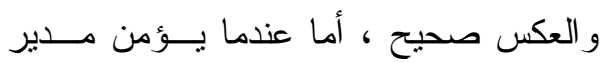

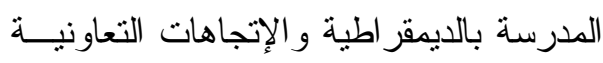
فإنه يدير المدرسة عــن طريــق المعلمــين

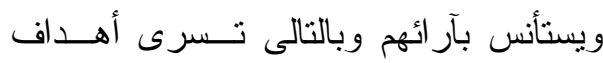

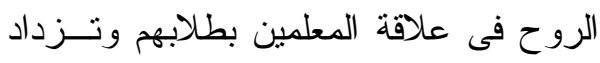

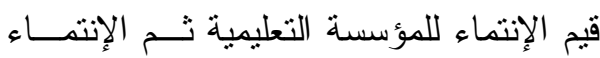

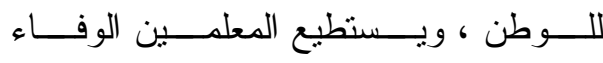

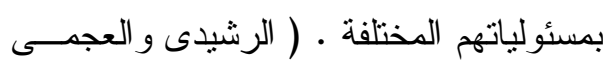
. ( I ro ، r.). ،

\section{دـ - تعزيز العلاقة بين الأسرة و المدرسة :}

إن بناء شخصية الفرد بنـــاء عقليــا

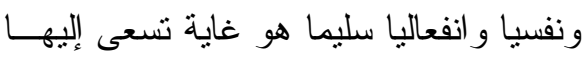
المؤسسات التزبوية، وتتكاتف جهودها لتحقيقه ، وتعتبر الإدارة المدرسية هي الحلقة الأهـــ

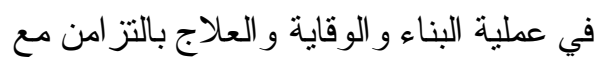
الأسرة ، فالمدرسة هي أحد المحاضن التـي ترعى خصوصيات المجتمع ومعتقداته ودينه
التربوية وتجديدها تبعاً لكل جديد ، و اقتاعـهـ

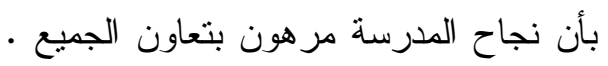

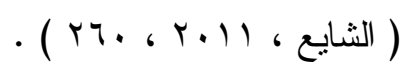
ويمكن للإدارة المدرسية من خــلدل تحليها بدرجة ملائمة من المرونة في تعاملها

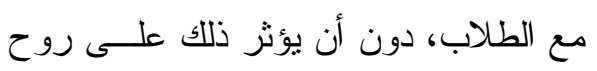

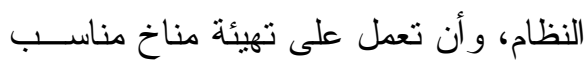

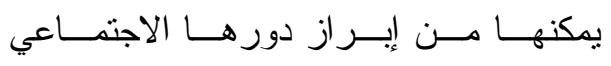

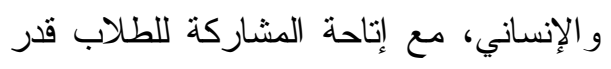

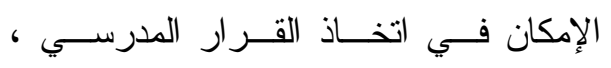
و الاهتمام بالطرق و الوسائل المناسبة لتعزيز الأمن الفكري ، ومن هذه الوســائل العنايـــة

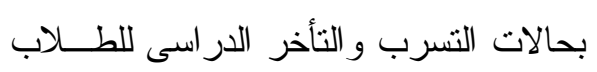

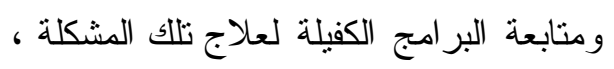

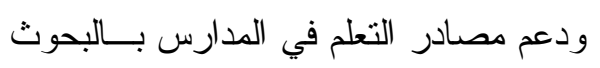

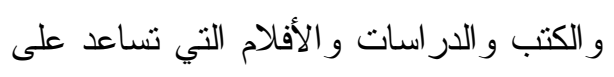

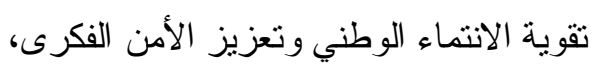

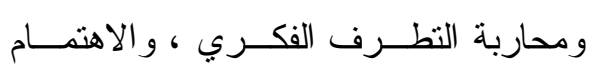

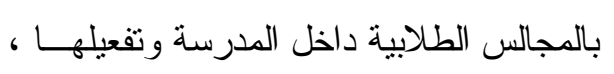

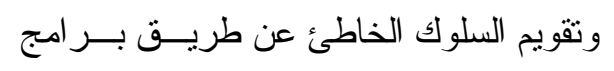

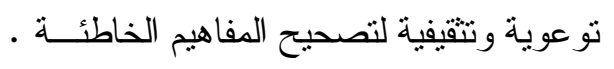

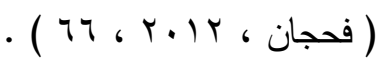
ج - غرس قيم التسامح فى نفوس الطلاب : فالإدارة المدرسية وما يسودها مسن نسامح هى روح نسرى من القمة إلى القاعدة ، فعندما يتصف مدير المدرسة بالتسلط ويقيم

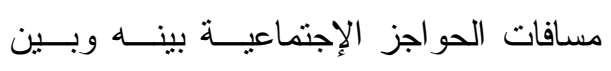


الاتصـال الفعال وتقويـــة جـسور العلاقــات الوثيقة بين المدرســـة و الأســرة و المجتمـــع خارج المدرسة من ناحية ثانية ، وذللك مـن أجل تحسين البيئات المدرسية ، وتـسخير ها لخدمة الطلاب و المجتمع المدرسى ، وتوفير الأمن و الإستفرار لهم على المــدى القريــب

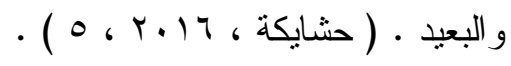

ه - تكريم الطلاب المتميزين سلوكياً على مستوى المدرسة :

تعد الطريقة التى يدير بهـــا مــديرو

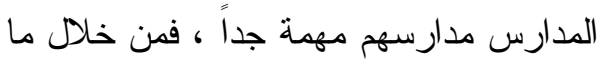
يبذلون جهد ، وينظمون ويتققدن كل الأمور المتعلقة بالمدرسة التى تؤثز فــى التحـــيل الأكاديمى للطلاب وللعملية التعليمية ، فدور قادة المدارس محورياً وأساسياً ، فإذا غرسوا فى الطلاب إحساساً بالمسئولية إزاء السلوك

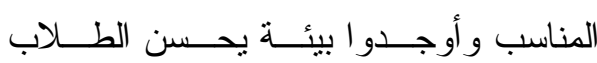
التعرف إليها ، فــان المــشكلات الـسلوكية ستصبح نادرة وخاصة عند مساعدة المدرسة للطلاب فى تحمل المسئولية تجاه ســلوكهم ، وبذللك يصبح من الممكــن دعــم تحـــيل الطلاب وتوفير البيئة المدرسـية الآمنــة .

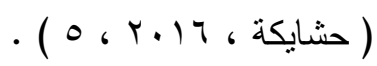

و آدابه ، ومن هنـــا فــان الإدارة المدرســية بوصفها القيادة التربوية في المدرسة يقع عليها مسئولية تربية الجيل تربية إسلامية سـليمة .

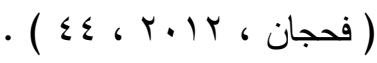
و إرشاد الطلاب إلى الصواب فى حالة مو اجهة تصور ات خاطئسة ومعرفــة ورلـى الامر، وتوجيه المعلم وإرشاده إلى الصو اب ولفت نظر المعلم رسمياً عندما يتجاوز فـى لـى بعض المعلومات بتبليغ إدارة التعليم. ( فرج . $(V), r \ldots \varepsilon$ ، وتكمن وظيفة الادارة المدرسية فـى التزكيز على كيفية المحافظـــة علــى القــيم الاجتماعيــة النبيلـــة ، و إكـــــاب الطــلاب المهار ات و الاتجاهات و المعارف التى يقـاوم من خلالها التطرف الفكرى، كما يتم إكسابهم المهار ات الصالحة و التزركيـز علــى تعلــيم المهن التى تمكنهم من تــوفير احتياجـــاتهم

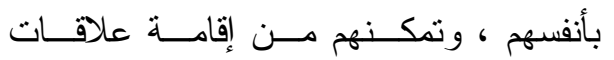
إجتماعية و إنسانية فاعلة ، وليس هذا فحسب بل محاولة تعليمهم التأثير علــى الآخــرين و المساهمة فى خدمة المجتمع مساهمة فعالة وذللك بالتتسيق مع الأســرة ( القرطــون . ( $\varepsilon)_{6}, r_{\text {.. V }}$ ولذلك أصبّح من الــضرورى قيــام المدرسة و علــى رأســـها الإدارة المدرســية

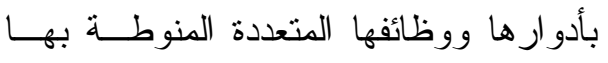
داخل المدرسة من ناحية ، وتـــــيم قنــــوات 
فالعدالة المدرسية تتعلق بالعلاقة بـين

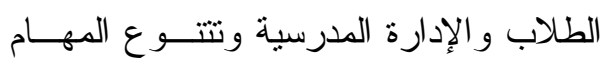

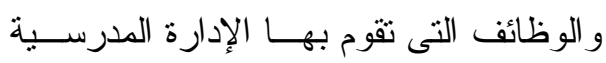

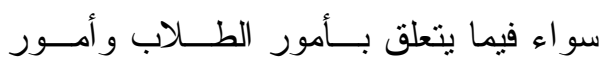

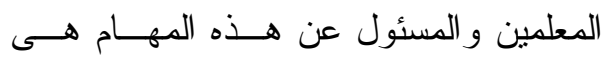

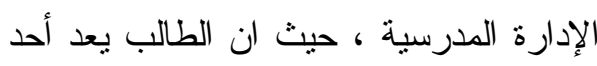

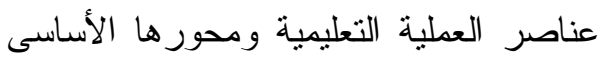

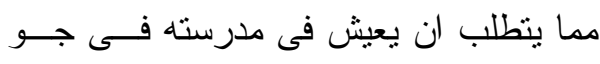

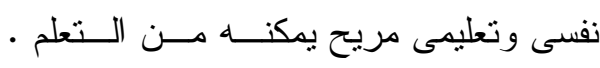

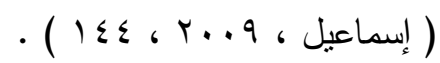

و على الإدارة المدرسية أن تـدرك أن جميع الطــلاب متــساويين فــى الحقــوق و الو اجبات ، مع الإعتر اف بقيمــة الطالــبـ

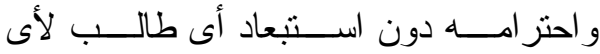
ظروف مرتبطة به ، حيث ان المديريين إذا

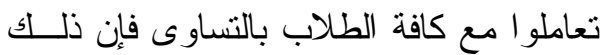
يدفع الآخرين فى بيئة المدرسة لأن يسسلكوا نفس هذا الـسلوك , Daniles ,Bradley . ( 2011,75)

وقد أكد عدد كبير من الباحثين علـى لـ

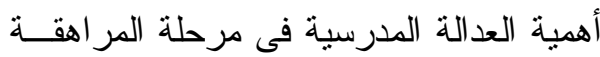
حيث ترتبط درجــة تــوافر العدالــة بـين فين

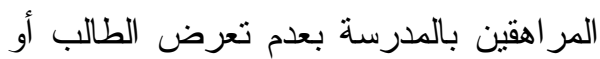
مشاركته فى العديد من السلوكيات الخطـــرة

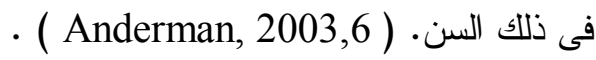

و - تعزيز المعاملة بالعــل و المسـساواة

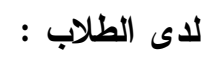

العدالة بصفة عامــة مطلــبـ مهـــ

وضرورى لكل من يعيش على الأرض مــن أجل أن يهنأ بحياته ويشعر بالرضا و والسعادة وحب العمل و العطاء ، و العدالة ليست حكراً

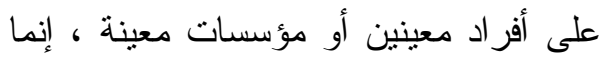

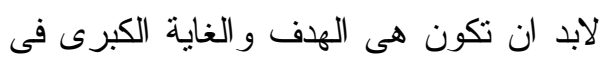

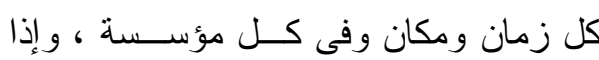

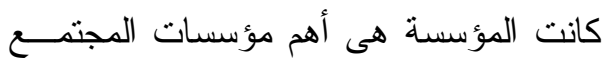

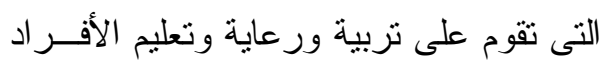

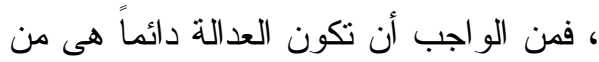

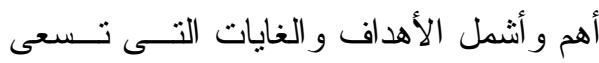
وتعمل تللك المدارس من أجل تحقيقها بكافــة

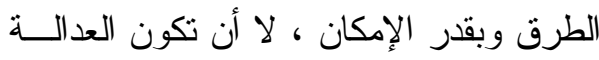
مجرد شعار دون وجود حقيقى لهـــا داخــل

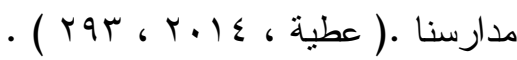
وتؤكد الإدارة المدرسية على العـدل

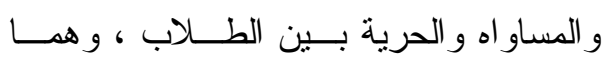

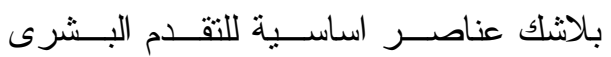

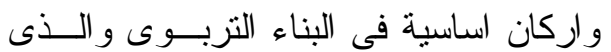

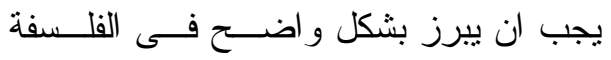

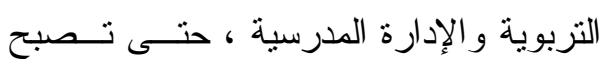

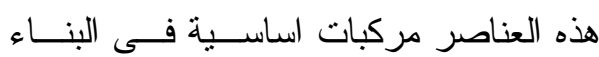

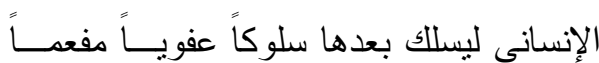

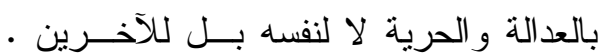

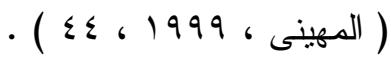




$$
\begin{aligned}
& \text { رأيه أمام كل عيارة ( مو افق _متــردد } \\
& \text { _ غير موافق ) } \\
& \text { • - تم عرض الاســنبانة فــى صــورتها } \\
& \text { المبدئية على بعض السادة المحكمــين }
\end{aligned}
$$

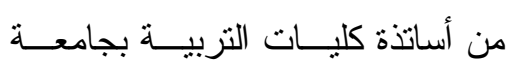

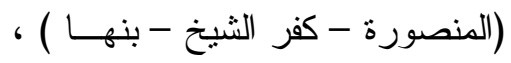

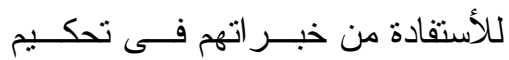

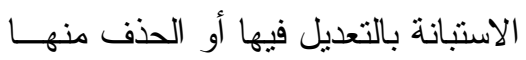

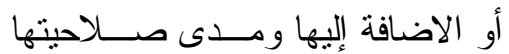

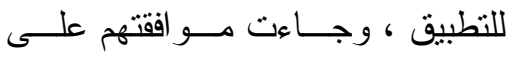

$$
\begin{aligned}
& \text { الاستبانة بمثابة تحقيق الصدق للأداه } \\
& \text { • - بعد إجر اء التعديلات التى اشـار إليهـــا }
\end{aligned}
$$

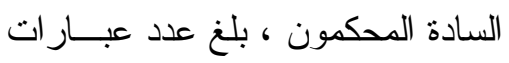

$$
\begin{aligned}
& \text { الاسنبانة ست عبار ات } \\
& \text { تم حساب الثبات للاستبانة باســتخدام } \\
& \text { برنامج الرزم الإحصائية للعلوم الإجتماعيــة } \\
& \text { statistical package for (spss) } \\
& \text { Social sciences }
\end{aligned}
$$

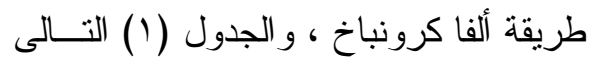

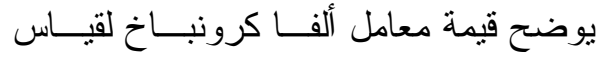

$$
\begin{aligned}
& \text { الثبات للاسنبانة }
\end{aligned}
$$

\section{إجرايات الدراسة اليدانية ونتائجها}


و الجدول (r) التالى يوضح عــدد المعلمــين بكل إدارة من الادارات الثناثة

جدول (r)

أ - توصيف عينة الدراسة وفقا للإدارة

\begin{tabular}{|c|c|c|}
\hline النسبة & العينة & الإدارة \\
\hline$\% \cdot, \leqslant \vee$ & $r \varepsilon$ & إدارة غرب المنصورة \\
\hline$\% \cdot, \leq \leq$ & rr & إدارة أجا التعليمية \\
\hline$\% \cdot, \cdot \wedge$ & 9 & إدارة الجمالية \\
\hline$\% 1 \ldots$ & vr & المجموع الكلى \\
\hline
\end{tabular}

( مديرية التزبية و التعليم بالدقهليــة ،

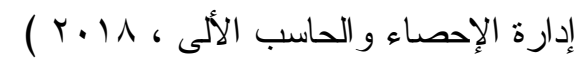

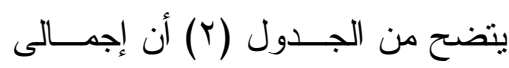

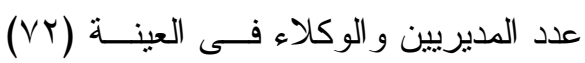

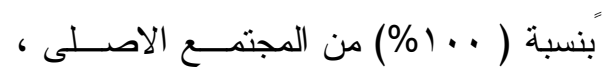

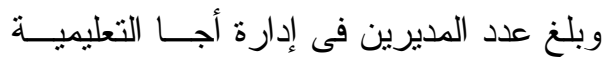

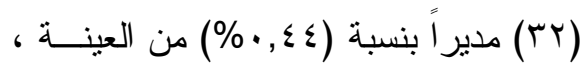

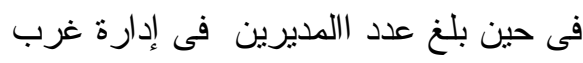

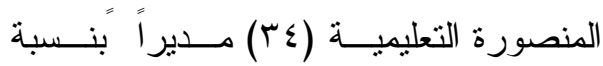

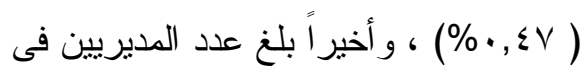

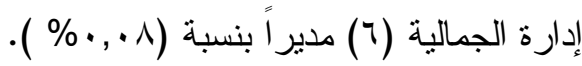

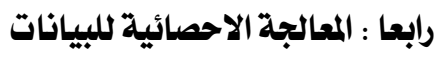
تم تفريغ البياتــات وتبويبهـــا واســتخدام الأساليب الإحصائية التالية

• - حـــــاب المتوســـــات الحـــسابية و الانحر افات المعيارية لجميع عبار ات
جدول (1)

معامل ألفا كرونباخ لقياس الثبات للاستبانة

\begin{tabular}{|c|c|c|}
\hline الثبات & رقدرة & المحور \\
\hline צדם, . & 1 & \multirow{6}{*}{ مور المدرسية في الإدارة } \\
\hline 0.882 & $r$ & \\
\hline 0.916 & $r$ & \\
\hline 0.987 & $\varepsilon$ & \\
\hline 0.811 & 。 & \\
\hline 0.945 & 7 & \\
\hline & & \\
\hline
\end{tabular}

يتضح من الجدول (1) أن قيم معامل

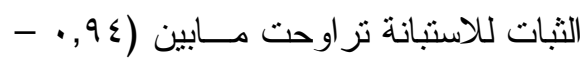
97 , · • ) و هى معاملات ثبات مرتفعة .

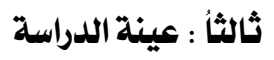

تكون المجتمع الاصلى للار اسة مـن

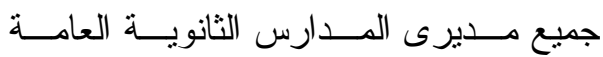
ووكلائها بمحافظة الدقهلية ، وقد تم اختيار

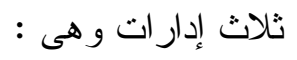

• إدارة غرب المنصورة التعليمية ممثلـــة

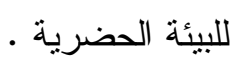

• إدارة أجـــــا التعليمبــــة ممنلــــة للبيئــــة

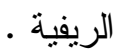
• إدارة الجمالية التعليميــة ممنلــــة للبيئـــة

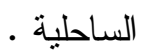

$$
\text { الاسنبانة . الأنرات }
$$


التقدير الرقمى = (بxتكرار مو افق

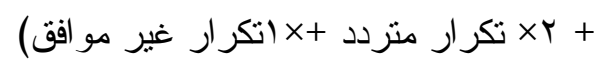

فـى حساب التكر ار ات المقابلـــة لكـــلـ

عبارة موزعة علــى الاســتجابات الثنلاتـــة

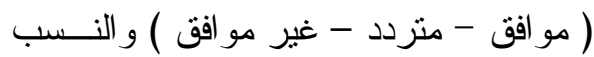

المئوية لهذه التكر ار ات و الاوز ان النسبية ـوردية

حساب الوزن النسبى لعبارات الاستبانة :

أعطيت موازين رقمية لمستوى الاســتجابة

\begin{tabular}{|c|c|c|}
\hline غير موافق & متردد & مو افق \\
\hline 1 & r & $r$ \\
\hline
\end{tabular}

خامساً : نتائج الدراسة اليدانية وتفسيرها :

دور واقع إدارة المدارس الثانوية العامة فى

مواجهة التطرف الفكرى لدى طلابها :

يبين الجدول (ع) التــالى آر اء أفـــر اد

العينة حول دور و اقع إدارة المدارس الثانوية

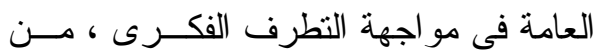

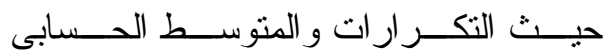

ودرجة المو افقة و الترتيب لكل عبــارة لآر اء

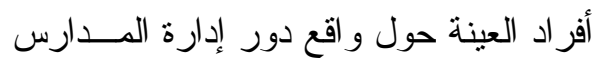

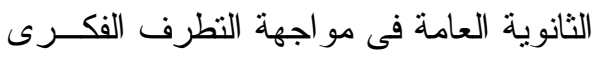

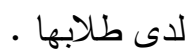

• - حساب مستوى المو افقة مــن خــلال

حساب المدى ، تم تحديد طول الفئــة

بقسمة المدى على عدد الفئات .

طول الفئة = أكبر قيمة _ أقل قيمة / عدد

الفئات = r

ويوضح الجدول (r) التالى درجة الموافقة

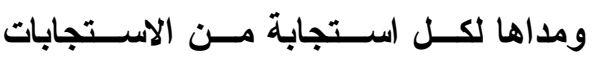

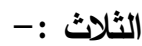

$$
\text { جلول (r) }
$$

درجة المو (فقة للاستجابات ومداها وفقاً

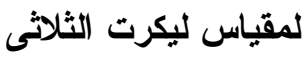

\begin{tabular}{|c|c|}
\hline درجة المو اققة & العدى \\
\hline منذفقة & $1,74-1$ \\
\hline متوسطة & Vז, \\
\hline كبيرة & $r-r, r \varepsilon$ \\
\hline
\end{tabular}

• - كما تم استخدام الاســاليب الاحــصائية

$$
\text { الآتية :- كماتم اسني }
$$

- حساب التكر ار ات ونــسبتها لكـلـل

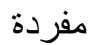

- حساب التقدير الرقمى لكل مفــردة

من خلال المعادلة الآتية : - - ل 
جدول (ء) التكرارات والمتوسط الحسابى ودرجة الموافقة والترتيب لكل عبارة لآراء أفراد العينة حول واقع دور إدارة المدارس الثانوية العامة فى مواجهة التطرف الفكرى لدى طلابها حول واقع دور الإدارة المدرسية فى مواجهة التطرف الفكرى

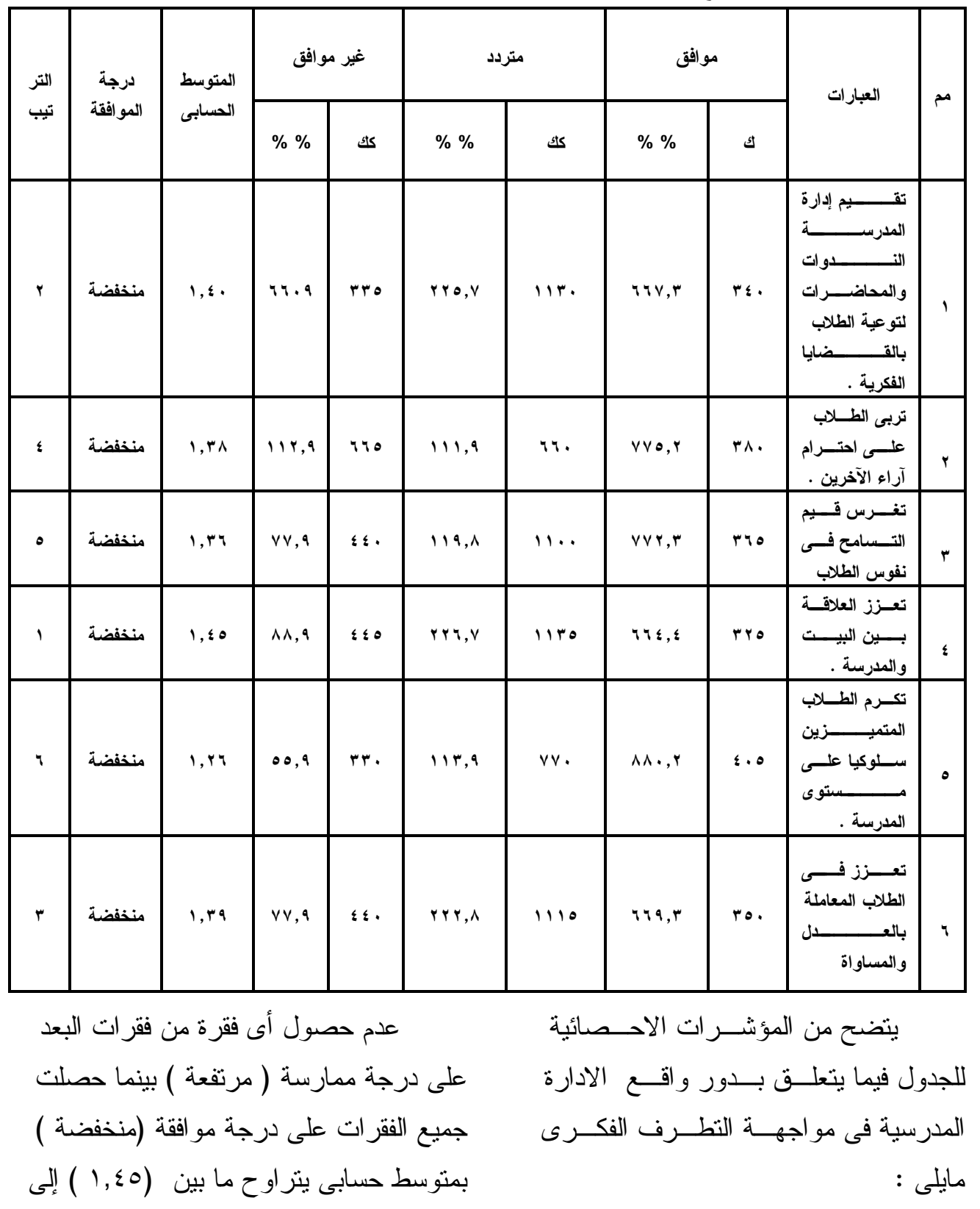




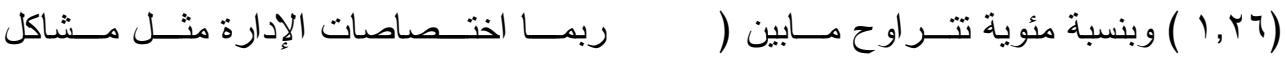

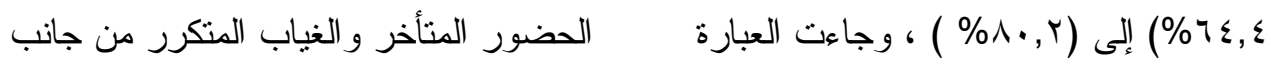

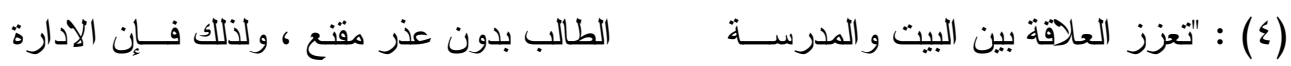

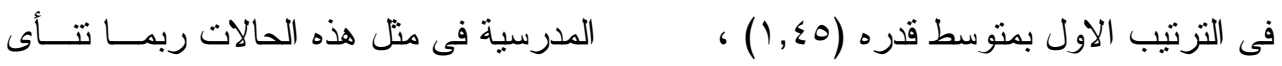

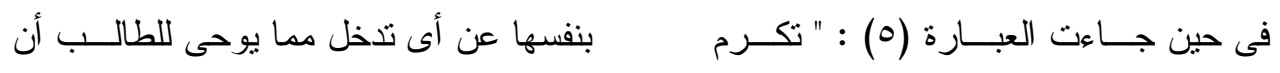

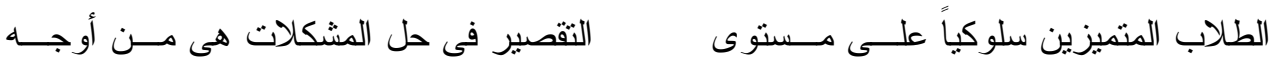

$$
\begin{aligned}
& \text { المدرسة فى الترتيب الاخير بمتوسط قـدره القصور التى تحسب على عائق الادارة . } \\
& \text { التوصــيات المقترحسـة لـــدور إدارة }
\end{aligned}
$$

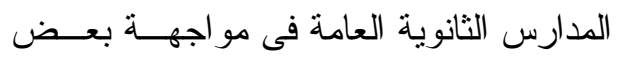

$$
\begin{aligned}
& \text { مظاهر التطرف الفكرى لدى طلابها . } \\
& \text { - تشجيع الطلاب علي المشاركة في اعداد } \\
& \text { وتتفيذ البر امج و المشرو عات التي تخــدم } \\
& \text { المجتمع المحلي مثل بر امج حماية البيئة }
\end{aligned}
$$

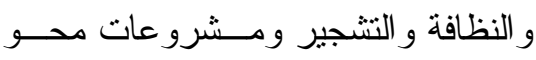

$$
\begin{aligned}
& \text { الامية وتعليم الكبار • } \\
& \text { - دعوة المتخصصين فـي محاضـــر ات }
\end{aligned}
$$

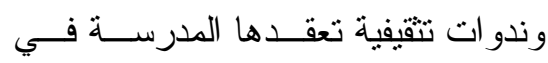

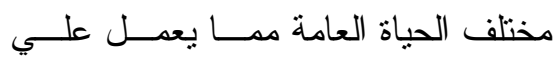

$$
\begin{aligned}
& \text { تعزيز الامن الفكري لاي الطلاب } \\
& \text { - اثر الك اولياء الامور في تتفيذ بر امج في }
\end{aligned}
$$

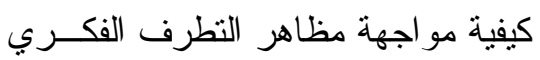

$$
\begin{aligned}
& \text { و اتخاذ القرار ات داخل المدرسة } \\
& \text { - تكرم الطلاب المتميزين ســلوكياً علـى ولى } \\
& \text { مستوى المدرسة } \\
& \text { - تعزز فـى الطــلاب المعاملـــة بالعـــل } \\
& \text { و المساو اة - معردي }
\end{aligned}
$$


خلال بناء علاقات ايجابية بـين المعلــم

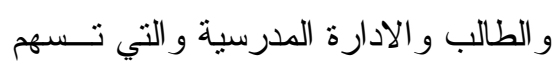

في بناء سلوك ديمقر اطي لدي الطلاب.

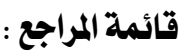

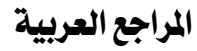

1- الخميسى ، السيد سلامه وبدوى ، باســـ

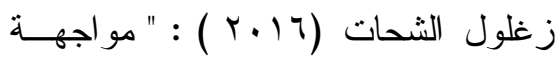

تحديات الامن التزبوى لتعزيــز الامــن فئن

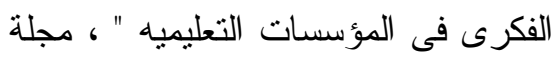

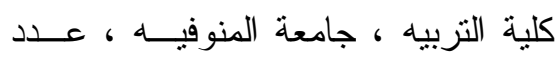
خاص ، السنه الو احده و الثنلاثون

r- الحوشـــان، بركــة بــن زامــل بــن

بركة(10 1 ب). "أهمية المدرسة في تعزيز

الأمن الفكري." الفكر الثرطي: القيــادة الهمئه

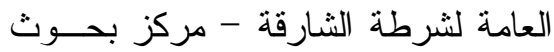

الشرطة مجع r، عـ

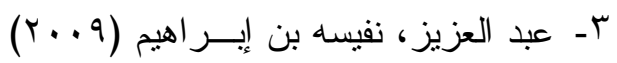

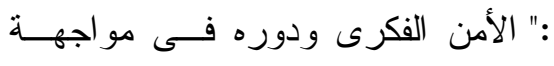

ظاهرة النطرف فى المجتمعات الاسلامية

، بحث مقــدم للمــؤتمر الــوطنى الأول

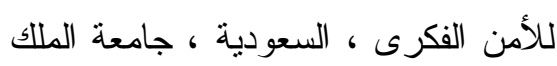

سعود - س

عـ - السعدني، فكري عبــــالمنعم محمــد، و

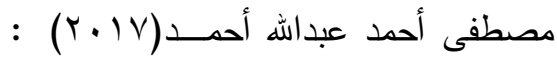

"استخدام معلمي التعليم الأساسي لأساليب

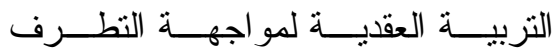

و الإر هاب: دراســة ميدانيــة." المجلـــة

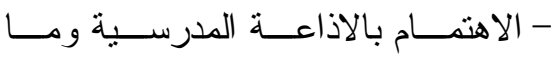

يصاحبها من تحية العلم وترديد النـشيد

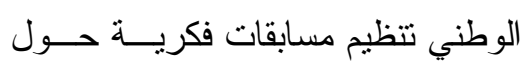

بعض القضايا الناريخية و الوطنية .

- تتظيم رحلات تزفيهية لمعرفة مكانــة

مصر وتعزيز الانتماءو الو لاء الوطنى

- التاكيد علي الثو ابت الوطنية في ثقافــة

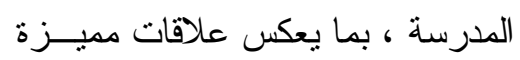

في طبيعة الادارة المدرسية تؤدي الـــي لـكي

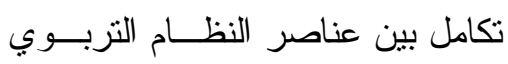

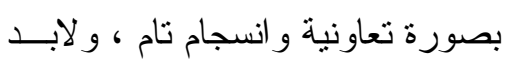

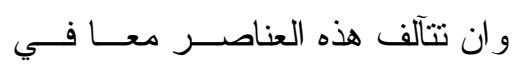

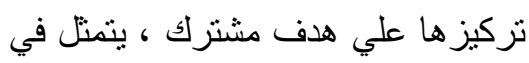

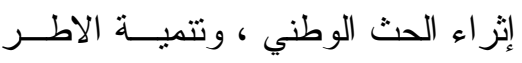

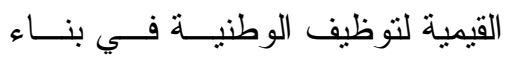

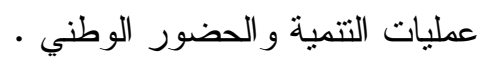

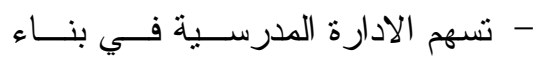

الثخصية الوطنية لدي الطــلاب مــن

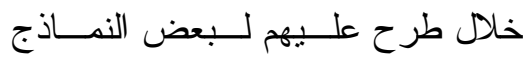

الوطنية و القامات القومية التي ساهمت

في المنجز الوطني ، الي جانب التركيز

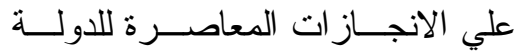

المصرية في عمليات التعليم المختلفة .

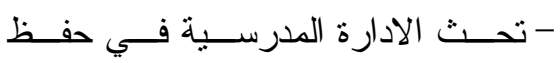

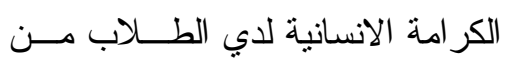




$$
\begin{aligned}
& \text { ظاهرتي الإرهـاب و التطــرف وســبل } \\
& \text { الدولية للعلــوم التزبويـــة و النفـــية: } \\
& \text { تطويره" ، مجلـــة الجامعــة الإســلامية }
\end{aligned}
$$

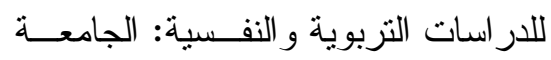

$$
\begin{aligned}
& \text { الإسلامية بغزة - شئون البحث العلمــي ولي }
\end{aligned}
$$

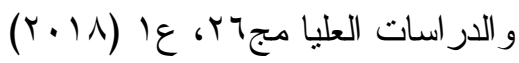

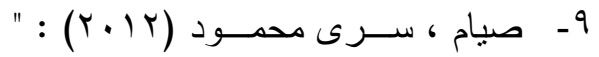

$$
\begin{aligned}
& \text { الدور الفكرى للمؤسسات التزبويــة فـى } \\
& \text { مو اجهة الغلو و التطرف " ، الحلقة العلمية }
\end{aligned}
$$

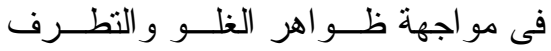

$$
\begin{aligned}
& \text { المؤدية للإزهاب خلال الفتـرة } 19 \text { - } 19
\end{aligned}
$$

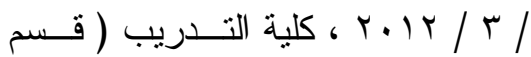

$$
\begin{aligned}
& \text { البر امج التدرييية ) ، الرياض } \\
& \text { • }
\end{aligned}
$$

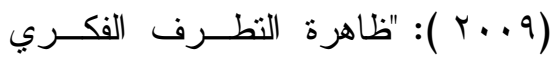

$$
\begin{aligned}
& \text { و التربوي عندطلاب كليات التربية للبنين }
\end{aligned}
$$

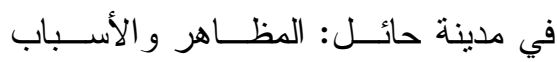

$$
\begin{aligned}
& \text { و الحلول المقترحة در اسة ميدانية." مجلة } \\
& \text { القر اءة و المعرفة: جامعة عين شــمس - } \\
& \text { كلية التربية - الجمعية المصرية للقراءة }
\end{aligned}
$$

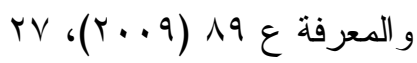

$$
\begin{aligned}
& \text { |1-محمد، محمد النـصر حسن(10 + ب) : } \\
& \text { "التربية الوقائية للمؤسسات التربوية فــي } \\
& \text { مو اجهة التطرف الفكري." در اسات فــي لئي } \\
& \text { التعليم الجامعي: جامعة عــين شـمس - }
\end{aligned}
$$

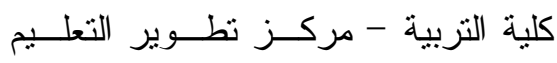

$$
\begin{aligned}
& \text { الجامعي عابه التريله } \\
& \text { العدد (110) ، يونيو ، الكوبت ، }
\end{aligned}
$$


المدرسى حسب اتجاهات تلاميذ المرحلة

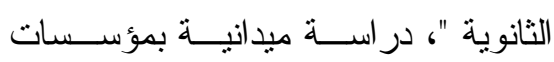

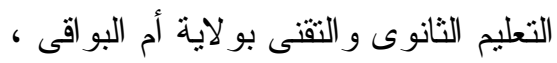

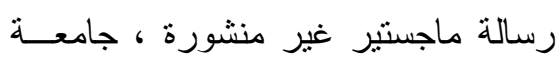

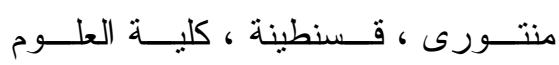
الإنسانية و الإجتماعية ، قسم علم الــنفس كله و علوم التربية .

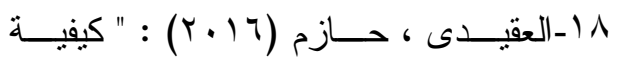
صناعة التطــرف ، التتـشئة الــسياسية ودور ها

19-القحطانى ، سالم بن على سالم (1991 )

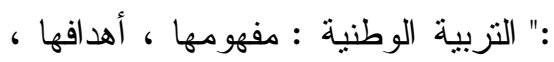

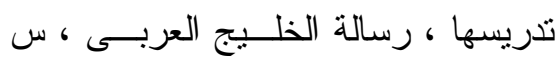

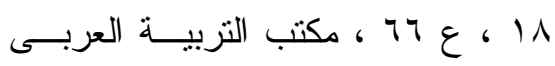
لدول الخليج

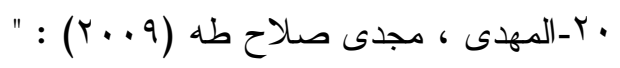
مشروع الثرق الأوسط الكبير" ،الآليات - التداعيات - المو اجهة ، رؤية تربوية الاوسية ، المنصورة ، دار الوفاء للطباعة و النشر كروبه لوريه

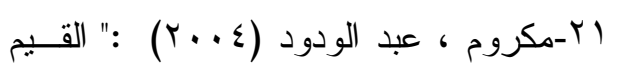
ومسئوليات المواطنة رؤية نربوية ، دار الفكر العربى ، القاهرة

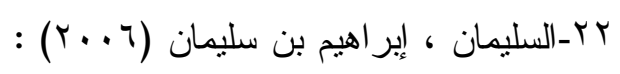

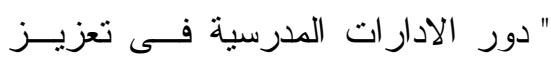
الامن الفكرى للطلاب " ، دراسة ميدانية

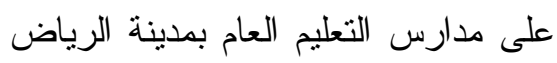

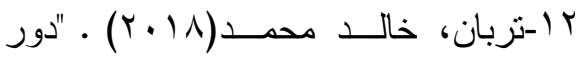

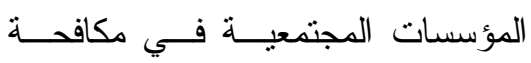

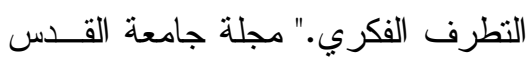

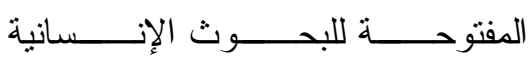
و الاجتماعية: جامعة القدس المفتوحسـة $\varepsilon \varepsilon \varepsilon$

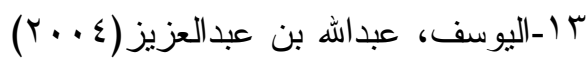

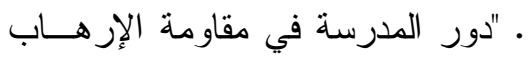

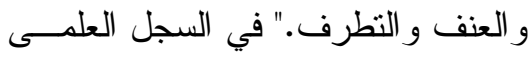
لمؤتمر موقف الإسلام من الإرهــاب: جامعة الإمام محمد بن سعود الإسلامية الرياض: جامعة الإمام محمد بن سعود

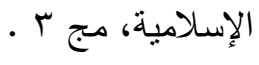

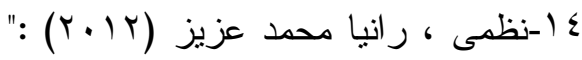

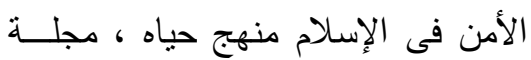

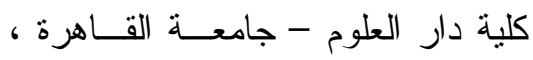

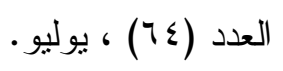

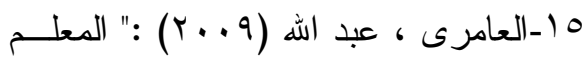

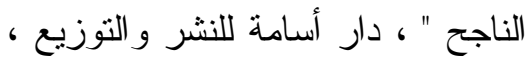
عهــــان ، الاردن ، مكتبـــــة نـــــــن الإلكترونية

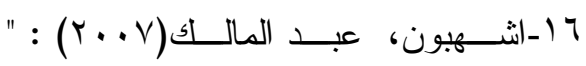
العنف المدرسى ، المظاهر ، العوامل ، بعض وسائل العلاج IV

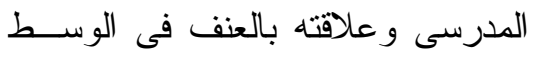


ماجستير غير منشورة ، جامعة النجــاح

الوطنية ، كلية الدراسات العليا ( الإدارة التربوية ) ، نابلس ، فلسطين ، النهات

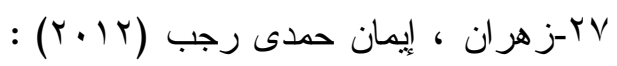

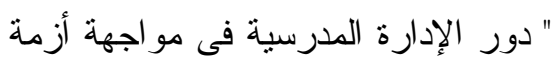

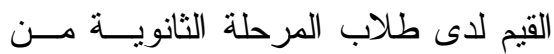

التعليم الأساسى فى ضوء متغير ات القرن

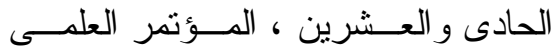

الحادى عشر ( أزمة القيم فى المؤسسات

التعليمية ، كلية التربية ، جامعة الفيـوم

$r_{1}+1 r_{6}$

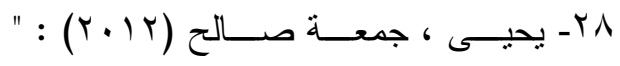

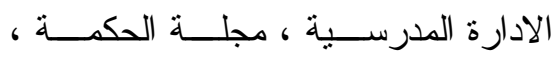

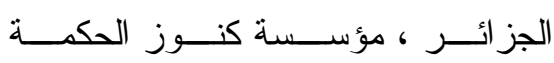

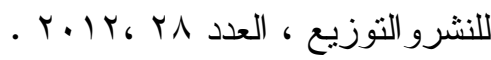

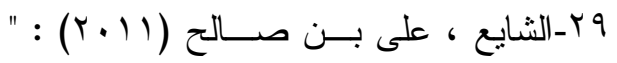

دور الادارة المدرسية فى تعزيز الأنتماء

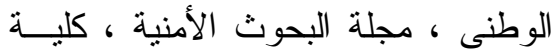

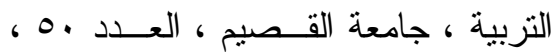

. r. II

• ץ-الرشيدى ، حسين ، و العجمى ، حجــاج

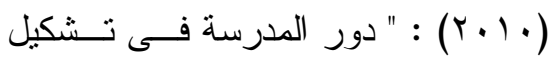

الوعى السياسى لطلاب المرحلة الثانويــــة

بالكويت ، العدد الأول ، يناير · ـ . r.

آ- فرج ، عبداللطيف بن حسين بن إير اهيم

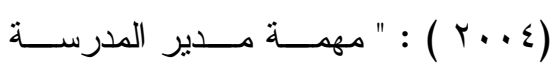

، جامعة نايف العربية للعلوم الامنية ، كلية الدراسات العليــا ، قـــم العلـــوم

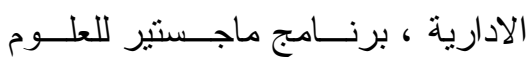

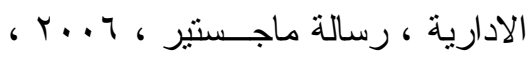
ص ابr ، ص סץ .

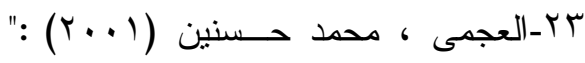

الإدارة المدرسية "، دار الفكر العربى ، القاهرة ، مصر ، 01:00

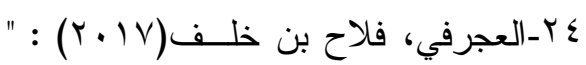

دور الإدارة المدرسية في مو اجهة الفكر بن المتطرف بين طلاب المرحلة الثانويــة بمحافظة الدو ادمي: در اســـة ميدانيــة."

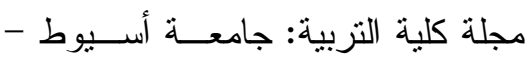

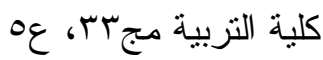
هץ-فحجان، نصر خليل، و سليمان حسـين موسى المزين(r(ץ) ـ "دور الإدارة المدرسية فى تعزيز الأمن الفكرى لدى

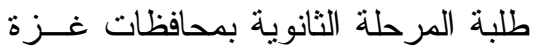
وسبل تفعيله" رسالة ماجسنير • الجامعة

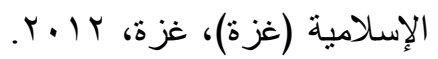

Tr-حشايكة ، شــيرين عـدنان إســماعيل

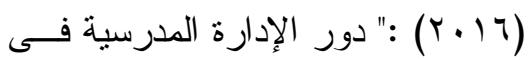

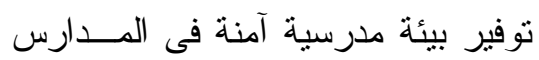
الحكومية الاساسية فى محافظات شمال

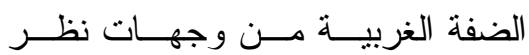

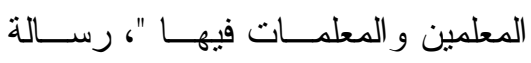


التربوية و المتطلبات المستقبلية: جامعــة

الكويت - كلية التزبية الكويــت قـسم

الإدارة و التخطيط التزبوي - كلية التربية

- جامعة الكويت ومؤسسة الكويت للتقدم

العلمي، (1999)

דr-إسماعيل ،محسن محمد (9 . . ץ) :" مدى

تحقيق مبدأ العدالة فى التعلــيم الثــانوى

العام من منظور إسلامى (در اسة ميدانية

) ، رسالة ماجستير (غير منـشورة ) ) ،

كلية التزبية ، جامعة الزقازيق •

المراجع الأجنبية : - ماجية

1- Alexandris, k .Tsorbatzoudis ,C .\& grouios,G .(2002). Perceived constraints on recreational sport participation: Investigating their relationship with intrinsic motivation and extrinsic motivation. Journal of leisure Research, Vol., 34 , No, .3. 233252

2- Anderman, L , H . (2003). Academic and Social perceptions as Predictors of change in middle school student sence of school Belonging Journal of Experimental Education, vol ( 72), No ( 1), 5-22

1- Bloder, Chirema (2006): The Causes Of Extremity in Changing World, Toronto University, PP39 -150

$$
\begin{aligned}
& \text { الثانوية تجاه السلوك المنحــرف لــدى } \\
& \text { الثباب من وجهة نظر مديرى المدارس } \\
& \text { الثانوية الملتحقين بالــدورة التدريبيـــة } \\
& \text { بجامعة أم القرى ، در اسات فى المناهج } \\
& \text { وطرق التدريس ، مصر ، ع 9 9 . . }
\end{aligned}
$$

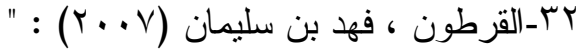

أثز المدرسة في تفعيــل دور طــلاب

المرحلة الثانوية لمو اجهة الإزهـــاب

در اسة تطبيقية من وجهة نظر طـلاب

وطالبات الثانوى بمحافظـــة عنيـزهـ ،

رسالة ماجسنير غير منشورة ، جامعة

نايف للعلوم الأمنية ، كلية الدر اســات

$$
\text { العليا ( قسم العلوم الثرعية ) }
$$

سM-عطية، إحسان شكري، نصر محمــود

صبرى، فاتن فاروق عبدالفتاح موسى، لإن،

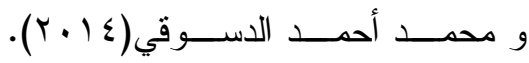
"العدالة المدرسية و علاقتهـــا بالانتمـــاء المدرسي لاى تلامبذ الــصف الثــاني الإعدادي." مجلة كلية التربية: جامعــة

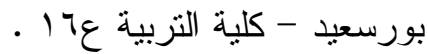

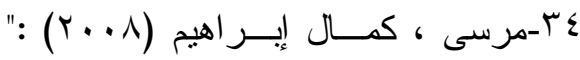
الاسرة و التوافق الاسرى " ، القاهرة : دار النشر للجامعات .-.

هب-المهينـــي، محمـــد صـــالح(1999) :

"الإدارة المدرسية و التطلعات المستقبلية"

، في المؤتمر الــدولي حـــول الإدارة 
schools, African Journal of History and Culture,2(1), 1-9

10-Satocard, Jean. (2013). Continuity and change in values in middle age. Journal of Experimental Research on Ageing, number 2, www.sctandfonline.com . 26

11-Smits, A., Van Gaalen, R. I., \& mulder , C .H . (2010) . Parent- child coresidence : who moves in with whom and for whose needs ?. Journal of Marriage and Family, 72 (4) , 1022-1033 .

12-Todd C., Helmus, E., Peter C. (2014). Promoting Online Voices for Countering Violent Extremism, RAND Corporation research report series

13-Turay. T. M (2005).:" Peace education. In International Encyclopedia of Adult Education. Edited by Leona M English". New York: Macmillan Publishers

14-Warmer, B. (2010), Segmenting the Electorate: The Effects of Exposure to Political Extremism Online. Communication Studies, 61(4), pp. 430- 444.

15-Webster.(1984).Webster's New Dictionary of Synon yam, Merriam Webster, Inc, Publisher, USA.
4- Daniels , J .A . „\& Bradley, m.c. (2011) . Bulding appositive school climate preserventing lethal school violence Advancing responsible adolescent development . Dol 10,1007\978-1-4419-8107-3$6, \mathrm{c}$ springer science + Business media , $11 \mathrm{c}, 2011$

2- Davies, L. (2004).:" Education and Conflict: Complexity and Chaos" . New York: Routledge Falmer. Retrieved September 23,2019, from Questiadatabas

6- Davydov, D. (2015), The Causes of Youth Extremism and Ways to Prevent It in the Educational Environment, Russian Social Science Review, 56(5), pp. 51-64

3- Guzzetti Barbara j. \& William, wayne (2004) . Examining Intellectual safety in The seine Classroom . journal of Research in science Teaching. vol 33 .no 1 .

8- Larsson, Richard (2005): Editorial Intolerance And Extremism, Canada, Varian Press

4- Nakpodia, E.D, (2010), Culture and curriculum development in Nigerian 